\title{
Leverage, CEO Risk-Taking Incentives, and Bank Failure during the 2007-2010 Financial Crisis
}

\author{
Patricia Boyallian ${ }^{1}$ and Pablo Ruiz-Verdú ${ }^{2}$ \\ ${ }^{1}$ Lancaster University Management School, Department of Accounting and Finance; \\ ${ }^{2}$ Universidad Carlos III de Madrid, Department of Business Administration
}

\begin{abstract}
Usual measures of the risk-taking incentives of bank CEOs do not capture the risk-shifting incentives that the exposure of a CEO's wealth to his firm's stock price (delta) creates in highly levered firms. We find evidence consistent with the importance of these incentives for bank CEOs: In a sample of large U.S. financial firms, a higher pre-crisis delta is associated with a significantly higher probability of failure during the 2007-2010 financial crisis in highly levered firms, but not in less levered firms.
\end{abstract}

JEL Classification: G30, G21, G34, M12

Keywords: executive compensation, risk-taking incentives, leverage, banks, financial crisis.

\footnotetext{
*We are grateful to Franklin Allen, the editor, and an anonymous referee for their comments and suggestions. The authors acknowledge the financial support of Spain's Ministry of Science and Innovation (through research grant ECO2009-08278), Spain's Ministry of Economy and Competitiveness (through grant ECO2012-33308), Fundación UCEIF (through a 2013 Santander Financial Institute research grant), and Madrid Autonomous Community (through grant S2015/HUM-3353 (EARLYFIN-CM)).
} 


\section{Introduction}

The view that bankers' compensation created the incentives that led to the latest financial crisis has prompted numerous proposals to regulate pay at financial institutions. ${ }^{1}$ However, despite the attention devoted to executive pay by regulators, extant research provides mixed support for the hypothesis that CEO compensation in the run-up to the crisis influenced bank risk taking. Thus, although some authors, such as DeYoung et al. (2013), find a positive relation between CEO risk-taking incentives and bank risk or policy choices, others find no such relation. Notably, Fahlenbrach and Stulz (2011) find no significant relation between the most commonly used measure of the risk-taking incentives generated by executive compensation (vega) and bank performance during the crisis.

In this paper, we argue that standard measures of the risk-taking incentives generated by executive compensation, which focus on the incentives generated by stock options, do not capture a potentially large component of bank CEOs' incentives to take on risk, namely the incentives generated by their stock holdings. Indeed, because of limited liability, equity holders have the incentive to shift risk to debtholders and other claim holders (Jensen and Meckling, 1976; Galai and Masulis, 1976), and this incentive is especially strong for the equity holders of highly levered firms, such as large U.S. financial institutions. Therefore, we test the hypothesis that a greater sensitivity of a CEO's wealth to his firm's stock price (delta), by aligning the CEO's incentives with those of shareholders, will increase the CEO's risk-taking incentives in highly levered banks but not, or to a lesser degree, in banks with low leverage.

To investigate the relation between CEO risk-taking incentives prior to the financial crisis and risk, we use failure during the crisis period (2007-2010) as the measure of firm risk. We measure risk ex post to capture the tail risk that is unlikely to be captured by standard risk measures if they are computed prior to the crisis (as in Cheng et al., 2015 or DeYoung et al., 2013). To account for the possibility that regulators may intervene to prevent the default of some banks by brokering their acquisition by healthier ones, we use an encompassing definition of bank failure that includes not only closures but also acquisitions of distressed banks with the intervention of supervisors. As a case in point, on March 16, 2008, Bear Stearns agreed to be acquired by JPMorgan for $\$ 2$ per share, which represented a more than $90 \%$ discount relative to the previous closing price (although the acquisition price was subsequently raised to $\$ 10$ per share). The Federal Reserve brokered the deal and provided financial assistance by funding the purchase of Bear Stearns'

\footnotetext{
1 Section 956 of the 2010 Dodd-Frank Act requires that the banking agencies regulate compensation arrangements at large financial institutions to discourage inappropriate risk taking, and, in 2011 and 2016, the agencies proposed rules to regulate pay in financial institutions. Outside of the United States, regulatory action has been intense as well. The European Union approved directives CRD III (in 2010) and CRD IV (in 2013), which contain provisions that regulate compensation at financial institutions, and the Committee of European Banking Supervisors (in 2010) and the European Banking Authority (in 2015) issued guidelines on sound remuneration policies. In the United Kingdom, the Financial Services Authority issued in 2009, and amended in 2010, the so-called Remuneration Code, and the Prudential Regulation Authority and the Financial Conduct Authority issued remuneration rules for financial firms in 2015. At the multinational level, the Financial Stability Forum issued the Principles for Sound Compensation Practices in 2009.
} 
troubled assets. Although Bear Stearns did not default, our measure considers it a failed financial institution.

We estimate the relation between risk-taking incentives measured in year 2006 and bank failure in the period 2007-2010 for a sample of large U.S. financial institutions. Our results show that, whereas a higher delta is associated with a significantly higher (both statistically and economically) probability of failure in highly levered firms, it does not have a significant relation with the probability of failure in less levered firms. In line with the findings of Fahlenbrach and Stulz (2011), we find no significant relation between bank failure and the sensitivity of the value of CEOs' stock option portfolios to the volatility of their firms' stock (vega). The results are robust to the use of different sets of control variables, specifications, or subsamples. They also hold, albeit in weaker form, if we measure bank risk by means of distance to default, the corresponding expected default frequency, buy-and-hold returns, market beta, or stock price volatility, measured during the financial crisis. Therefore, our evidence is consistent with the hypothesis that the risktaking incentives generated by CEO compensation influenced firm risk among financial firms, although we also discuss alternative non-causal explanations for our findings.

We also estimate the relation between compensation incentives, leverage, and risk in the periods before (2003-2006) and after (2011-2014) the crisis. In these periods, firm failures are too infrequent among the relatively large listed firms in our sample to be used as a measure of risk, so we use, instead, the measures of distance to default and expected default frequency proposed by Bharath and Shumway (2008) as alternative measures of the risk of failure. The results for the periods outside the crisis are weaker, but generally in line with the ones we find during the financial crisis. We interpret our results as suggesting that risk measures computed in normal times do not incorporate financial firms' exposure to correlated tail risk.

In addition to the work by Fahlenbrach and Stulz (2011) and DeYoung et al. (2013) cited above, several articles have analyzed the relation between CEO compensation and bank risk in the wake of the financial crisis. Gande and Kalpathy (2015) show that vega before the crisis is positively associated with the amount of U.S. Federal Reserve emergency loans provided to banks, which they use as an ex post measure of bank risk. Bhagat and Bolton (2014) examine the net payoff obtained by the CEOs of 14 of the largest U.S. financial institutions during the period from 2000 to 2008, as well as CEOs' trades of their own stock during the same period, and conclude that CEO compensation in those firms generated incentives for excessive risk taking. Bennett et al. (2015) and Brown et al. (2015) focus on different components of CEO compensation: Bennett et al. (2015) find a negative relation between bank CEOs' debt-like compensation (inside debt) and bank risk during the financial crisis, and Brown et al. (2015) show that severance pay is related to bank risk. Cheng et al. (2015) put forth an alternative explanation of the relation between CEO compensation and bank risk, in which banks' exogenously-given riskiness determines the (optimal) CEO compensation, and find results consistent with their proposed explanation. Finally, Bebchuk and Spamann (2010) and Bebchuk et al. (2010) analyze case studies of executive compensation at large U.S. financial institutions and propose compensation reforms. $^{2}$ Our main contribution to this literature is that we propose and find support for

2 There are some earlier studies of the relation between CEO compensation and bank risk taking, notably Houston and James (1995) and John and Qian (2003). Laeven and Levine (2009) and Erkens et al. (2012) also analyze the relation between bank governance and bank risk for international samples of large financial institutions. 
the hypothesis that the compensation of bank CEOs generates risk-taking incentives, but the sign and strength of those incentives depend on bank leverage. Our contribution is complementary to recent ones by Anderson and Core (2015) and Chesney et al. (2012), who also highlight the fact that equity holdings may generate incentives to take on risk in highly levered firms. These authors propose structural valuation models to obtain a measure of the sensitivity of the value of CEOs' equity holdings to the volatility of the firm's assets and, in the case of Chesney et al. (2012), relate their measure to bank asset write-downs during the crisis. We discuss further the relation between our results and those obtained by Anderson and Core (2015) and Chesney et al. (2012) in Section 6.. We further contribute to existing work by using an encompassing definition of failure, which accounts for the acquisition of firms in distress, as our main measure of risk. ${ }^{3}$ This ex post measure of risk is meant to account for the tail risk that materialized during the crisis, which standard measures of risk computed prior to the crisis may not capture. Finally, we use a comprehensive set of control variables to account for other sources of incentives or firm or CEO characteristics that may be related to both firm risk and CEO compensation, including termination payments (as in Brown et al., 2015), inside debt (as in Bennett et al. 2015), governance variables, complexity measures, and CEO characteristics, such as CEO age or wealth.

\section{Delta, Leverage, and CEO Risk-Taking Incentives}

In a levered firm, any increase in firm value above the amount owed to debtholders is fully appropriated by shareholders. At the same time, limited liability implies that shareholders' losses are limited to their initial investment. Therefore, a long line of work in corporate finance, starting with Jensen and Meckling (1976) and Galai and Masulis (1976), argues that leverage creates incentives for shareholders to take on risk, since greater risk redistributes firm value from debtholders to shareholders. Moreover, the incentives to take on risk increase as leverage increases. Figure 1 illustrates this point. For a firm with low leverage, such as firm A, the mean-preserving spread depicted in the figure does not change the expected equity payoff. However, for a highly levered firm, such as firm B, the same mean-preserving spread increases the payoff to equity holders if asset returns are high, but does not reduce the payoff if returns are low, thereby increasing equity holders' expected payoff. A greater sensitivity of a CEO's wealth to his firm's stock price (delta), by increasing the extent to which the CEO benefits from increases in expected equity value, would, thus, increase the risk-taking incentives of the CEO of the highly levered firm (B), but not of the CEO of the firm with low leverage (A). ${ }^{4}$

3 Bennett et al. (2015) use actual default as one of their measures of bank risk.

4 Standard option pricing models can generate these predictions. The payoff for the shareholders of a levered firm is similar to the payoff of a call option on the firm's assets with a strike price equal to the face value of the firm's debt (Black and Scholes, 1973; Merton, 1973). Thus, standard valuation models imply that the value of the equity of a levered firm is increasing in the volatility of the firm's asset value. These models also imply that the sensitivity of the value of an in-the-money call option to the underlying asset's volatility increases as the value of the underlying asset gets closer to the strike price. For the case of equity, this means that the sensitivity of equity value to asset volatility increases as the value of the firm's assets and the face value of debt get closer, or, in other words, as leverage increases. 
Because of leverage, a higher delta increases a CEO's incentives to increase risk so as to transfer firm value from debtholders to equity holders. However, a greater delta may also strengthen a CEO's risk-taking incentives by increasing the extent to which the CEO benefits from investing in risky projects that increase firm value. Thus, a CEO whose compensation consists solely of fixed pay will not invest in risky projects that increase the firm's expected value if those projects increase the probability of failure, since the CEO does not benefit from increases in firm value if the firm does not fail, and failure implies giving up future fixed pay. If the CEO receives stock or stock options, he will benefit from increases in firm value if the firm does not fail, so he may invest in risky projects that increase the firm's expected value, even if doing so increases the probability of failure. The greater the CEO's delta, the more he will benefit from the increases in equity value generated by risky, value-increasing projects. Thus, a greater delta will increase his incentives to undertake these risky projects. In the Online Appendix, we show that the hypothesis that a higher delta increases CEO risk-taking incentives more in more levered firms can, in fact, be derived formally from a model similar to the one proposed by John and John (1993) to study the relation between leverage and compensation incentives.

The above arguments show that a high delta may increase CEOs' risk-taking incentives by increasing the extent to which they benefit from risky policies that increase equity value. However, a higher delta may also reduce the risk-taking incentives of a risk-averse CEO by increasing the cost of greater equity risk for the CEO. The restricted stock and executive stock options that are part of executives' compensation packages are typically subject to vesting restrictions and are not tradeable. Moreover, CEOs are typically not allowed to hedge their exposure to their firms' stock price. Therefore, a CEO's ability to reduce his exposure to his firm's equity value is limited. As a result, an increase in equity risk will translate, other things equal (in particular, keeping expected equity value constant), into a lower expected utility for a risk-averse CEO. Moreover, the impact of the increase in equity risk on the CEO's expected utility will be greater the greater the exposure of the CEO's wealth to the firm's equity returns. Therefore, a higher delta may create incentives to reduce risk (Guay, 1999). Because of this reason, several articles that analyze the relation between CEO risk-taking incentives, as measured by vega, and firm risk introduce delta as a control variable (Guay, 1999; Knopf et al., 2002; Coles et al., 2006; Brockman et al., 2010).

The net sign and magnitude of the effect of an increase in delta on a CEO's risk-taking incentives will depend on the CEO's risk tolerance and the return distribution of the projects available to the firm. However, the risk-shifting incentives generated by leverage imply that the effect of a higher delta on CEOs' risk-taking incentives will more likely be positive and of a greater magnitude in more levered firms. Therefore, we propose testing the hypothesis that a higher delta reduces the probability of failure less, or increases the probability of failure more, in more levered firms. To the best of our knowledge, this hypothesis has not been previously tested in the literature on CEO risk-taking incentives, although Chesney et al. (2012) and Anderson and Core (2015) test whether firm risk is associated with measures of risk-taking incentives that take into account the impact of leverage on the option value of equity.

As emphasized by the prior empirical literature on CEO risk-taking incentives, CEOs' stock option holdings can generate additional risk-taking incentives. Executive stock options are call options on the firm's stock and, thus, exhibit a convex relation between the option's payoff and the value of the underlying stock. This convexity implies that both the expected payoff and the market value of a call option are increasing in the volatility 
of the underlying stock. Thus, Guay (1999) proposed to use the vega of a CEO's portfolio of stock options, which measures the sensitivity of the value of the CEO's option portfolio to changes in the volatility of stock returns, as a measure of the CEO's risk-taking incentives. However, even if the market value of an executive stock option is increasing in stock volatility, a higher stock volatility need not increase the expected utility of a riskaverse CEO who cannot freely trade or hedge the option, because, as discussed above, the higher volatility increases the risk of the executive's option and stock portfolio (Lambert et al., 1991; Guay, 1999; Ross, 2004; Ingersoll, 2006; Lewellen, 2006). Notwithstanding this criticism, most recent papers analyzing CEOs' risk-taking incentives measure these incentives by means of vega (e.g., Knopf et al., 2002; Coles et al., 2006; Brockman et al., 2010; Fahlenbrach and Stulz, 2011). In keeping with this literature, we also consider option vega as a measure of the risk-taking incentives of bank CEOs.

\section{Data}

We select all firms covered by the compensation database ExecuComp with a 4-digit SIC code between 6000 and 6300 and that are alive in year 2006. The SIC code reported by ExecuComp corresponds to the year in which information about the firm was last retrieved. Therefore, we use the historical, time-varying, SIC code reported by the CRSP US Stock Database to identify firms' SIC codes as of year 2006. We include in the sample all firms whose SIC code in 2006 is equal to 602 (Commercial Banks), 603 (Savings Institutions), or 6712 (Offices of Bank Holding Companies) - a total of 114 firms -, and we exclude from the sample firms with SIC code 6111 (Federal Credit Agencies). To determine the inclusion in the sample of the firms in the remaining SIC codes, we search the National Information Center of the Federal Financial Institutions Examination Council (FFIEC) to verify each firm's institution type in year $2006 .{ }^{5}$ We keep a firm in the sample if it is identified as any type of regulated institution, which implies that the firm is a depository institution or controls depository institutions (such as banks or savings and loan associations). ${ }^{6}$ Following Cheng et al. (2015), we also keep in the sample those firms listed as primary dealers by the New York Fed. This step leads to the inclusion in the sample of the large investment banks not selected in prior steps (Bear Stearns, Goldman Sachs, and Merrill Lynch). ${ }^{7}$ This process yields a base sample of 134 firms in 2006, from which we

\footnotetext{
5 These firms have SIC codes: 6099 (Functions Related to Depository Banking, Not Elsewhere Classified), 6141 (Personal Credit Institutions), 6159 (Miscellaneous Business Credit Institutions), 6162 (Mortgage Bankers and Loan Correspondents), 6172 (Finance Lessors), 6199 (Finance Services), 6200 (Security and Commodity Brokers), 6211 (Security Brokers and Dealers) and 6282 (Investment Advice). We access the National Information Center of the FFIEC at http://www.ffiec.gov/nicpubweb/nicweb/SearchForm.aspx.

6 The classes of regulated institutions are: bank holding company, financial holding company, savings and loan holding company, federal savings bank, national bank, state member bank, FDIC-insured non-member bank, federal savings association.

7 We obtain the historical list of primary dealers from https://www.newyorkfed.org/ markets/pridealers_current.html\#tabs-2 and match it with our sample manually by name.
} 
drop five firms because there is not enough information to compute delta. ${ }^{8}$ Therefore, our final sample has 129 firms. We report our final sample in Appendix 1..

We follow the exact same procedure for the years 2002 and 2010 to select the samples that we use in Section 5.7 to replicate the analysis for the periods from 2003 to 2006 and from 2011 to 2014 , respectively.

Since we obtain compensation data from ExecuComp, our sample is composed of relatively large, publicly traded financial institutions. ${ }^{9}$ The sample contains the largest listed bank holding companies, which range from holding companies with national presence (such as Citigroup, Bank of America, or Wells Fargo) to regional bank holding companies (such as Fifth Third Bancorp., National City Corp., or Regions Financial Corp.), or companies operating mainly in one or two states (such as Anchor Bancorp Wisconsin Inc. or Tompkins Financial Corp.). The sample also contains mortgage lenders (such as Countrywide Financial, IndyMac, or Washington Mutual), the five largest investment banks (Bear Stearns, Goldman Sachs, Lehman Brothers, Merrill Lynch, and Morgan Stanley), and several companies (such as American Express Co. and Charles Schwab) that have regulated depository subsidiaries. ${ }^{10}$

We obtain accounting information from Compustat Fundamentals and market data from CRSP.

To compute delta and option vega, we follow standard practice in the literature (Guay, 1999; Core and Guay, 2002; Coles et al., 2006) and define delta as the approximate change in the value of the CEO's stock and stock option portfolio associated with a $1 \%$ change in stock price, and vega as the approximate change in the value of the CEO's stock option portfolio associated with a 0.01 change in stock price volatility. More concretely, we define:

$$
\begin{gathered}
\text { Delta }=\left[n_{S}\left(\frac{S}{100}\right)\right]+\left[\sum_{i} n_{i} \frac{\partial O^{i}}{\partial S}\left(\frac{S}{100}\right)\right], \\
V e g a=\sum_{i} n_{i} \frac{\partial O_{i}}{\partial \sigma_{S}} \times 0.01,
\end{gathered}
$$

where $n_{S}$ is the number of shares of stock held by the CEO, $S$ is the stock price, $n_{i}$ is the number of options of option grant $i$ held by the CEO, $O_{i}$ is the Black-Scholes value of an option of grant $i$, modified to account for dividend payouts, and $\sigma_{S}$ the volatility of stock returns. We follow the procedure detailed by Coles et al. (2013) to compute the different variables in expressions (1) and (2) from ExecuComp data. ${ }^{11}$ In those specifications in which incentives are measured before 2006, both delta and vega are calculated using the one-year approximation technique described in Core and Guay (2002). This al-

\footnotetext{
8 We drop Center Financial Corp., with SIC 6036, because it does not match with Compustat Fundamentals. We drop Bankunited Financial Corp., Commerce Bancshares Inc., First Financial Bancshares Inc., and Guaranty Financial Group Inc. because there is not enough information to compute our measures of risk-taking incentives.

${ }^{9}$ Our sample selection procedure excludes Federal Credit Agencies. Thus, for example, Fannie Mae is not in our sample.

10 Although we often refer to the firms in our sample as banks, they are really holding companies, most of which control bank subsidiaries.

11 We depart from the procedure by Coles et al. (2013) only in that we use as risk-free interest rate the one provided by ExecuComp.
} 
ternative methodology for early years is necessary since the strike price and the maturity of individual option grants are not available until year $2006 .^{12}$

We measure leverage (following Fahlenbrach et al., 2012) as the ratio of the quasi-market value of the firm (measured as the book value of assets minus the book value of equity plus the market value of equity) divided by the market value of equity. Table 1 provides descriptive statistics of the incentive measures, leverage, and several firm characteristics computed in year 2006. Both delta and vega display substantial dispersion and, especially in the case of delta, are highly skewed. ${ }^{13}$ Although the distribution of leverage is less disperse, there is also substantial variation in leverage among the firms in the sample, with the 90 th percentile being more than double the 10th percentile.

\section{Research Design}

\subsection{Risk Taking and Failure}

Our measure of risk taking in the years preceding the crisis is an encompassing measure of bank failure during the crisis period. To date the crisis, we follow the timelines provided by the New York Fed (which dates the beginning of the "financial turmoil" in June 2007, when Bear Stearns pledged $\$ 3.2$ billion to aid one of its hedge funds $)^{14}$ and the Saint Louis Fed (which dates the beginning of the financial crisis in February 2007, coinciding with Freddie Mac's announcement that it would no longer buy the riskiest subprime mortgages and mortgage-related securities) $)^{15}$ and define 2007 to be the first year of the financial crisis.

Because of the potentially systemic importance of many of the financial firms in our sample, regulators may be expected to intervene to encourage sound firms to acquire financially distressed ones so as to avoid actual default. Identifying failure with default would, thus, not capture the instances of financial distress in which the regulators' intervention averts failure. Moreover, even in the midst of a financial crisis, outright default of large financial institutions is too rare to allow for a precise estimation of the coefficients of interest. Therefore, we define bank failure so as to encompass both institutions that default and those that are acquired by other financial institutions with the support or intervention of regulators.

More precisely, we first identify which firms in our sample are delisted in the period 2007-2010 by analyzing the series of monthly returns in the CRSP stock database. This

\footnotetext{
12 We note that for year 2006 we also compute the incentive measures differently for five firms because of data availability. Starting December 15, 2006, SEC disclosure rules require firms to report disaggregated information of option grants awarded to CEOs. However, a few firms in our sample had an earlier fiscal year-end, so that they did not have to comply with the new disclosure requirement until the next fiscal year (2007). For such firms (Bear Stearns, Goldman Sachs, Lehman Brothers, Morgan Stanley, and Washington Federal Savings) we use the one-year approximation technique described in Core and Guay (2002) to compute delta and vega.

13 The skewness of delta is further underscored by the fact that the maximum value of delta (not reported in Table 1) is 45.16, very far from the 90th percentile (2.93).

14 http://www.ny.frb.org/research/global_economy/Crisis_Timeline.pdf.

15 http://timeline.stlouisfed.org/index.cfm?p=timeline.
} 
process yields a set of 31 delisted firms. However, firms may delist for reasons other than bankruptcy or financial distress. For example, firms may go private, merge, or be acquired for strategic reasons even if they are sound. To determine whether firms were delisted because of financial distress, we take the following steps:

1. We identify the main banking subsidiary of each firm in our sample from the firm's organizational hierarchy provided by the FFIEC's National Information Center. We classify a firm as failed if the FDIC indicates that the firm's main banking subsidiary was put into receivership or acquired with financial assistance from the Fed or the FDIC during the crisis period. ${ }^{16}$ We identify 10 firms as failed in this step.

2. Merger discount. Following the procedure used by Fahlenbrach et al. (2012), we use the SDC Platinum database to identify mergers and check whether delisted firms not classified as failed in the previous step are acquired with a discount in the crisis period. In particular, we identify three firms acquired with significant discounts (with one-day, one-week and one-month negative premia of above $30 \%$ ). We also consider as failed a firm (Mellon) acquired with a one-day small discount of $6 \%$, as well as a firm (Countrywide) that is acquired with a one-day positive premium of $40 \%$, but with one-week and one-month discounts of $18 \%$ and $28 \%$, respectively.

3. For those delisted firms that we do not classify as failed in the previous steps, we search the PROQUEST database using the company name and the following keywords: failed, bankrupt, intervened, closed. The PROQUEST search identifies one firm as failed (Lehman Brothers, which is identified from its Chapter 11 petition filing).

4. We finally perform a web search using standard search engines. This broader internet search indicates that one firm is acquired with substantial regulatory pressure (Merrill Lynch), another one with TARP aid given to the acquiring institution (National City Corp.), and another one after a large amount of TARP bailout money is given to the target institution (Provident Bankshares). ${ }^{17}$

The procedure identifies 19 firms in the sample as failed. We provide the list of failed firms, as well as the reason why they are identified as such, in Appendix 2.. ${ }^{18}$

16 We obtain the information about the main banking subsidiaries from: http://www2 . fdic.gov/idasp/main.asp.

17 In the case of Merrill Lynch, there were sustained rumors that the Federal Reserve had pressured Bank of America to carry out the acquisition, and Congressional hearings were held in 2009 to determine, among other things, whether the Government or the Federal Reserve had pressured or threatened Bank of America's management to acquire Merrill Lynch (see, e.g., Story and Becker, 2009). National City Corp. was acquired after being one of the few qualified banks that was denied TARP help. On the contrary, the acquirer (PNC) received TARP money a few weeks before the purchase of National City was announced, a move that was widely interpreted as a push by supervisors to force National City to agree to be acquired (see, e.g., Fitzpatrick et al., 2008). Finally, Provident Bankshares Corp. received $\$ 151$ million from TARP to prop up capital on Nov. 14, 2008. One month later, M\&T and Provident Bankshares Corp. announced that the former would acquire the latter for $\$ 401$ million.

18 Whereas media reports provide strong support for the identification as failed of most firms classified as such in steps two to four, the cases of Mellon and Provident Bankshares 


\subsection{Empirical Model}

To analyze the relation between CEO risk taking incentives and firm risk we estimate a model with a dummy variable equal to one if the firm fails during the crisis period as the dependent variable and the incentive measures and control variables measured prior to the crisis as independent variables.

We measure CEOs' risk-taking incentives in year 2006. This choice of measurement period is determined by several requirements. We require the measurement period to be sufficiently close to the crisis to be able to potentially attribute to the compensation incentives an impact on the probability of failure during the crisis. We also require that the incentive measurement period not be a crisis year for two reasons. First, to the extent that bank failure was motivated by actions taken by banks in the years prior to the crisis, the measurement of incentives would take place after the actions they were supposed to incentivize. Second, we would like to avoid capturing reverse causality: Measuring incentives during the crisis could capture the reaction of CEOs' compensation packages to negative realizations of uncertainty during the crisis. Selecting 2006 as the measuring period allows us to meet these two requirements and maximizes the availability and quality of the compensation data, since a new set of compensation disclosure requirements became effective in 2006: Starting in year 2006, firms were required to report pension benefits and ex-ante termination payments, as well as disaggregated information about strike price and maturity of option grants. Moreover, other studies use 2006 as their measurement period (e.g., Fahlenbrach and Stulz, 2011), which makes it easier to compare our results with theirs.

Testing for the presence of interactions in nonlinear models (such as logit or probit) is problematic (Greene, 2010), and our limited sample size makes estimation of nonlinear models imprecise. Since we are mainly interested in the interaction between delta and leverage, our preferred specification is, thus, the following linear probability model:

$$
\begin{aligned}
\text { Failed }_{i} & =\beta_{0}+\beta_{1} \ln (1+\text { Vega })_{i, 2006}+\beta_{2} \ln \left(1+\text { Delta }_{i, 2006}+\right. \\
& +\beta_{3} \ln (1+\text { Delta })_{i, 2006} \times \text { Leverage }_{i, 2006}+\beta_{4} \text { Leverage }_{i, 2006}+\mathbf{x}_{i, 2006} \gamma+\varepsilon_{i}
\end{aligned}
$$

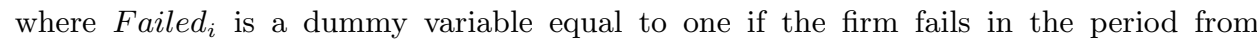
2007 to 2010 and $\mathbf{x}_{i, 2006}$ is a vector of controls. We include the natural logarithm of the compensation variables in (3) because of the positive skewness of the distribution of these variables (especially of delta). ${ }^{19}$ We also winsorize all compensation variables at the 2 nd and 98 th percentiles to reduce the influence of highly atypical observations. In Section 5.4, we discuss the robustness of our results to the specification of the estimating equation.

We note that, by construction, our ex post measure of risk is cross-sectional. Therefore, we cannot make use of fixed effects to control for time-invariant unobserved firm heterogeneity. $^{20}$

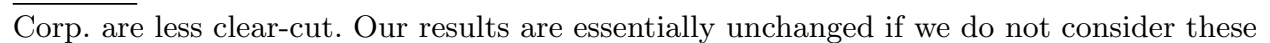
institutions as failed. Not considering as failed the three firms identified as such in the last step does not affect the results either.

19 We define the logarithmic transformation of each compensation variable $y$ as $\ln (1+y)$, because some compensation variables are equal to zero for some firms.

20 In principle, one could specify a panel model with fixed effects by measuring failure with quarterly or yearly frequency (instead of over the whole crisis period) and assuming that failure in period $t$ depends on incentives in periods $t-K_{0}$ to $t-K_{1}$, for some $K_{1} \geq K_{0} \geq 1$. However, to estimate such a model, one could exploit only the longitudinal variation in 


\subsection{Control Variables}

We include control variables that are likely to be related to firm risk or CEO risk-taking incentives. Moreover, several of these variables are correlated with delta and vega, so omitting them could bias the estimation of the coefficients of interest. Since we aim to capture the potential effect of risk-taking incentives on the likelihood of failure, we avoid, as much as possible, using as controls variables that could be the result of those incentives. To clarify this point, suppose that the credit risk of a bank's loan portfolio were the only variable determining bank risk. In this case, even if compensation strongly influenced CEOs' incentives to take on risk, we would observe no effect of compensation on bank risk if we controlled for the credit risk of the loan portfolio in our regressions. We emphasize that the goal of our analysis is not to accurately predict bank failure, but to estimate the relation between pre-crisis incentives and bank failure during the crisis.

Leverage. If leverage were largely outside the control of the CEO and had a significant effect on the probability of failure, then the estimated coefficient of the interaction between delta and leverage could capture the potential effect of bank leverage on the probability of failure, instead of the effect of CEO risk-taking incentives. Therefore, we include leverage as a control in all our regressions. The cost of including leverage as a control is that, to the extent that bank CEOs have the ability to influence leverage, and that leverage affects the probability of failure, controlling for leverage may bias the estimate of the relation between CEO risk-taking incentives and failure. For example, if CEOs with stronger risk-taking incentives were more likely to select high levels of leverage (as suggested by Gormley et al., 2013), and if higher leverage increased the probability of failure, then controlling for leverage would lead to an underestimation of the effect of risk-taking incentives on failure.

Bank size and complexity. Size may affect bank risk in different ways. Larger banks may be less risky to the extent that they benefit from greater diversification, economies of scale in risk management, or government support in case of distress. However, larger banks may be riskier if they are more complex and the greater complexity translates into greater risk, or if the belief that large banks are too big to fail allows these banks to increase their risk. At the same time, size is significantly correlated with all the CEO compensation variables. Therefore, we use the natural logarithm of total assets to control for firm size in all our regressions.

To account for the potential impact of bank complexity on bank risk, we also use four measures of complexity. First, we use the number of employees as an alternative measure of size that may incorporate the greater complexity of managing a large organization. Second, we use a measure of complexity reported by the Federal Reserve for U.S. domiciled bank holding companies. To categorize a bank holding company as complex the Federal Reserve considers, among other factors, the nature, riskiness, and scale of the company's non-banking activities, management factors, and the amount of public debt issued by the company. ${ }^{21}$ Third, for the subsample of bank holding companies, we consider those that

failure and incentives for the 19 firms that fail during the sample period. Moreover, the year-to-year variation in delta and vega is likely to be a rather noisy measure of the true underlying changes in CEO risk-taking incentives.

21 The Federal Reserve's complex indicator is the variable rssd905\%, reported in the Bank Regulatory - Bank Holding Companies database provided by Wharton Research Data Services (WRDS). This database contains information about bank holding companies made 
are designated as financial holding companies to be more complex, since financial holding companies typically engage in a much broader range of non-banking activities than other bank holding companies. ${ }^{22}$ Fourth, we consider as complex bank holding companies those that control at least two commercial banks. ${ }^{23}$ We note that the last three measures of complexity are only available for bank holding companies (which constitute $73 \%$ of the sample). Finally, we also consider banks with international operations as more complex. To identify whether a bank holding company has an international presence we use the information contained in several items in the financial statements that bank holding companies file with the Federal Reserve. ${ }^{24}$ For firms that are not bank holding companies, we determine their international presence manually from their annual reports. ${ }^{25}$

Total pay. Total pay may be correlated with CEOs' risk-taking incentives or firm risk for several reasons. First, total pay could be related to implicit incentives stemming from the threat of replacement. If CEOs are replaced only when firm performance is dismal, the threat of termination may provide incentives to reduce risk, since CEOs will seek to lower the probability of negative tail risk (see, e.g., Eckbo and Thorburn, 2003). On the other hand, if continuation as CEO requires being at the top of the distribution of performance, then the threat of replacement may provide incentives for taking on risk. Regardless of the sign of the relation between termination incentives and risk taking, the strength of termination incentives is likely to be stronger for CEOs with a higher total pay. Total pay could also be related to the quality of corporate governance and, as we discuss below, corporate governance may affect CEOs' incentives to take on risk. Finally, total pay could also be correlated with firm risk if the CEOs of inherently riskier firms need to be compensated for the extra risk or if riskier firms require more skilled CEOs and, thus, have to pay more to attract them.

Termination payments. Termination payments reduce the CEO's downside risk and, thus, increase his risk-taking incentives. Severance payments also increase the cost of CEO replacement and, thus, weaken termination incentives, and, as discussed above, the sign of the relation between termination incentives and risk-taking is a priori ambiguous. Termination payments could also be set in place in riskier firms ( $R a u$ and $\mathrm{Xu}, 2013$ ).

available by the Chicago Fed's financial reporting group: https://www.chicagofed.org/ banking/financial-institution-reports/index. We obtain all the data items produced by the Federal Reserve from the Bank Regulatory - Bank Holding Companies database.

${ }_{22}$ Item rssd9016 in the Federal Reserve's RSSD database identifies whether a bank holding company has been designated as a Financial Holding Company.

23 The median bank holding company in our sample controls only one commercial bank. Results do not change if we consider bank holding companies that control more than two, or more than three commercial banks to be complex.

24 In particular, we consider a firm to have international presence if any of the following items in the Consolidated Financial Statements for Bank Holding Companies (form FR Y-9C) or the Parent Company Only Financial Statements for Large Bank Holding Companies (form FR Y-9LP) is non zero: Combined Foreign Nonbank Subsidiary Assets (bhcp2793), Number of Foreign Nonbank Subsidiaries (bhcp2831), Quarterly Average of Interest-Bearing Deposits in Foreign Offices, Edge and Agreement Subsidiaries, and IBFS (bhck3404), and Trading Assets in Foreign Offices (bhck3542). All these items are retrieved from the Bank Regulatory - Bank Holding Companies database provided by WRDS. Finally, we also use the variable Number Of Foreign Offices from Compustat Bank.

25 We consider a firm to have international presence if it reports having offices, subsidiaries, or significant business abroad. 
Thus, we include both golden parachutes (termination payments contingent on a change in control) and severance pay not contingent on a change of control as controls.

Debt-like compensation. Defined benefit pension plans and deferred compensation are similar to debt claims. These debt-like claims (inside debt) may provide incentives to limit risk similar to those of debtholders (Sundaram and Yermack, 2007; Edmans and Liu, 2011; Anderson and Core, 2015). Indeed, Bennett et al. (2015) report a negative relation between CEOs' inside debt and bank risk. Therefore, we include inside debt, which we define as the sum of the present value of the CEO's accumulated pension benefits from all pension plans and the total aggregate balance of the CEO's deferred compensation plans (Cassell et al., 2012), as a control in our regressions.

Corporate governance and CEO autonomy. If the CEOs of poorly governed firms are paid more and higher pay is not accompanied by changes in compensation structure, the CEOs of poorly governed firms will have larger equity holdings and, thus, other things equal, higher delta and vega. Moreover, poorly governed firms may make greater use of equity compensation, especially stock options, because these forms of compensation can be justified as providing incentives to the manager and because the cost to the firm of these compensation vehicles may be easier to conceal or undervalue (Bebchuk and Fried, 2004). Therefore, delta and vega may be correlated with the quality of corporate governance. ${ }^{26}$ At the same time, governance quality may affect CEOs' risk-taking incentives. Thus, if entrenched CEOs are less likely to be replaced if the bank performs poorly, they may be more willing to increase risk. Alternatively, poor governance may decrease firm risk if less entrenched managers need to achieve stellar performance to keep their job (which would increase their risk-taking incentives), whereas average performance is enough for entrenched managers to avoid replacement. To the extent that entrenched managers earn greater rents, they may also be less inclined to follow policies that increase the probability of failure. ${ }^{27}$ To account for the potential association between governance and risk taking, we include several measures of governance quality as controls: board independence (measured as the percentage of directors who are independent); board size (since larger boards have often been described as less effective); Gompers et al. (2003)'s governance index (GIM index) and the Entrenchment Index of Bebchuk et al. (2009) (higher values of these indices denote greater managerial entrenchment); the ownership share of institutional blockholders (owning at least $5 \%$ of the firm's shares); a dummy variable (CEO duality) that indicates whether the CEO is also the chairman of the board; and the percentage of independent directors who joined the board after the current CEO was hired. We obtain the information about board independence, board size, CEO duality, and the percentage of independent directors hired after the CEO from RiskMetrics, BoardEx, and proxy statements. We calculate both the E-index and the GIM index using the Governance tables from the Institutional Shareholder Services (ISS, formerly known as RiskMetrics) following Gompers et al. (2003) and Bebchuk et al. (2009). The data on institutional shareholders comes from Thomson Reuters Institutional Holdings (13F) database, as retrieved from Wharton Research Data Services (WRDS).

${ }_{26}$ We note that one could also make the argument that CEO pay-performance sensitivity will be lower in poorly governed firms. For our purposes, either argument suggests the need to include measures of governance quality as controls.

27 Along these lines, Low (2009) shows that an increase in takeover protection leads to a reduction in firm risk in non-financial firms, and Morellec et al. (2012) report calibration results that indicate that more entrenched CEOs would choose lower leverage. 
Some of these governance variables can also be understood as measuring the degree of autonomy of the CEO. For example, the CEO's decision power may be less constrained in firms in which the CEO is also the chairman of the board, in firms in which most independent directors were appointed while the current CEO was in office, or in firms in which institutional shareholders have small ownership stakes and can, thus, commit not to curtail the CEO's initiative (Burkart et al., 1997). At the same time, CEO autonomy may be related to risk and pay-performance sensitivity. Thus, as argued by Prendergast (2002), a principal may direct the agent and monitor the agent's decisions in a stable environment, in which the principal knows what the agent should do. However, in more uncertain environments, the principal may grant greater discretion to the agent, so as to benefit from the information obtained by the agent while on the job. Greater agent discretion, in turn, requires a higher pay-performance sensitivity to elicit better decisions or greater effort from the agent. Therefore, the CEOs of firms operating in a riskier environment may both have greater autonomy and a greater delta.

$C E O$ age and tenure. The implicit incentives stemming from the threat of replacement are likely to be stronger for younger CEOs, since these CEOs may earn rents for a longer time if they are not replaced. CEOs' career concerns are also likely to be stronger for younger CEOs and for CEOs with shorter tenure, because less information about their abilities has accumulated and, in the case of age, because there are more years left in which they may benefit from a higher perceived ability. At the same time, career concerns may affect CEOs' risk-taking incentives (DeMarzo and Duffie, 1995; Breeden and Viswanathan, 1998). Therefore, we use as controls CEO age and tenure, both as CEO and as an employee of the firm, as well as the number of boards of listed firms at which the CEO has served, as an additional measure of the amount of publicly available information about the CEO's abilities. CEO age may also account for potential differences between younger and older CEOs in risk aversion or overconfidence. These personal characteristics may, in turn, determine the form of the CEO's compensation contract and, thus, be related to delta and vega.

CEO wealth. If CEOs' risk tolerance increases with their wealth, greater CEO wealth may lead to greater risk. At the same time, the optimal levels of delta and vega are likely related to CEOs' risk tolerance. Therefore, we use as a control variable the measure of nonfirm wealth provided by Dittmann and Maug (2007). This measure is constructed using historical data on CEO compensation and aims to capture the wealth not associated with the CEO's current holdings of his own firm's equity. ${ }^{28}$

\section{CEO Incentives and Bank Failure: Estimation Results}

\subsection{Main Results}

In Table 2 we report the results of estimating model (3) with different sets of control variables. To help evaluate the economic significance of the estimated coefficients for delta, at the bottom of every column we report the changes in the average predicted probability of failure associated with an increase in delta from its 25 th to its 75 th percentile for

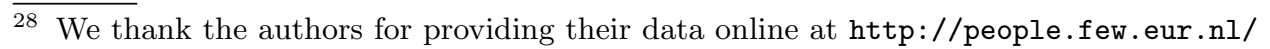
dittmann/data.htm.
} 
two values of leverage (leverage at its 25 th and 75 th percentiles). ${ }^{29}$ The results in the first column show that if leverage is not included in the regression, the coefficient of delta is positive and large (although not significantly different from zero at conventional significance levels), whereas the coefficient of vega is negative, small and not significantly different from zero. ${ }^{30}$ Thus, even though we use a different risk measure and have a different sample, our results without controls are broadly in line with the ones by Fahlenbrach and Stulz (2011), who find a positive relation between delta and risk and no significant relation between vega and bank risk. However, column 2 shows that if we include leverage and its interaction with delta, the relation between the probability of failure and delta is negative (or, at least, not significantly different from zero) for low values of leverage, whereas it is positive and significant (statistically and economically) for high values of leverage. Thus, an increase in delta from its 25th percentile to its 75 th percentile is associated with an increase in the probability of failure of 0.05 if leverage is at its 25 th percentile and of 0.09 if leverage is at its 75 th percentile. The latter increase is substantial in comparison to the unconditional probability of failure, which is 0.15 . These results suggest that a plausible interpretation of the positive coefficient of delta in column 1 is that, in highly levered firms, the risk-shifting incentives of delta outweigh the incentives it creates to moderate risk. Since the large U.S. financial firms in the sample are highly levered, on average, a higher delta increases risk-taking incentives among these firms.

In columns 3 to 8 of Table 2 , we add different sets of control variables associated with different potential explanations for the results in column 2: In column 3, we include variables that proxy for the strength of the incentives stemming from the threat of replacement (total pay, CEO age and tenure, severance pay, and the number of boards of listed firms at which the CEO has served); in column 4, we include total pay and inside debt to control for the risk-taking incentives stemming from the debt-like components of CEO compensation; in column 5, we include proxies for risk aversion (CEO age and wealth); in column 6, we include controls for governance quality (the Entrenchment Index, board independence, board size, the ownership share of institutional blockholders, the fraction of independent directors elected after the appointment of the current CEO, and a dummy variable indicating whether the CEO is also the chairman of the board) $;^{31}$ and in column 7 , we include controls for complexity (number of employees, international presence, a com-

29 Letting $\widehat{P}($ Delta, Leverage, Vega, $\mathbf{x})$ denote the predicted probability of failure, given values of Delta, Leverage, Vega, and the vector of control variables $\mathbf{x}$, and letting Delta $_{p}$ and Leverage $_{p}$ denote the p-th percentile in the sample distribution of Delta and Leverage, respectively, the reported values are: $75-25$ (Lev. L) = $\frac{1}{N} \sum_{i=1}^{N} \widehat{P}\left(\right.$ Delta $_{75}$, Leverage $_{L}$, Vega $\left._{i}, \mathbf{x}_{i}\right)-\frac{1}{N} \sum_{i=1}^{N} \widehat{P}\left(\right.$ Delta $_{25}$, Leverage $_{L}$, Vega $\left._{i}, \mathbf{x}_{i}\right)$, for $L=25$ and $L=75$, where $N$ denotes the size of the sample.

30 In all tables, we report robust standard errors. The standard errors of the coefficients for delta and its interaction with leverage are similar if we use classical standard errors instead. We do not report robust standard errors clustered by state or subsector, because of the limitations of these standard errors when the number of clusters and the sample size are small. However, clustered standard errors do not differ much from the ones reported in Table 2 and, as we show in Section 5.2, results do not change qualitatively if we add subsector dummies.

31 If we include the GIM Index instead of the Entrenchment index in column 6, its coefficient is not statistically significant either, and we obtain similar coefficients for delta and its interaction with leverage. 
plexity dummy that captures whether the Federal Reserve considers the firm a complex institution, and a dummy variable indicating whether the firm controls more than one bank). Finally, in column 8 , we include a set of controls that includes variables from the different columns. ${ }^{32}$ The signs of the coefficients of delta and its interaction with leverage are consistent across all specifications, and the latter coefficient is statistically significant in all specifications. The magnitude of the estimated coefficients is, however, different in two groups of specifications: the ones reported in columns 2, 5, 6 and 8, and those reported in columns 3,4 , and 7 . This difference may suggest that some control variables can partly explain the relation between risk, delta and the interaction of delta with leverage. However, the difference in the magnitude of the estimated coefficients is not due to the different sets of controls, but to the different composition of the subsamples with information about the control variables included in each specification. As we explore further in Section 5.2, the differences in coefficient estimates are due mainly to the presence in the full sample of the major investment banks, which are not in the subsample of bank holding companies in column 7 and several of which are not in the subsamples with information on termination payments or inside debt (columns 3 and 4). In fact, if one estimates the model in column 2 (with only firm size as a control) for each of the subsamples in columns 3 to 8 , the coefficient estimates are essentially identical to the ones reported in those columns. Alternatively, if one estimates the different specifications in Table 2 on the subsample of firms included in all columns, the coefficient of the interaction between delta and leverage is statistically significant in all specifications (even though this subsample is very small), similar to the one reported in column 7 , and barely changes across specifications. We report these results in the Online Appendix.

The last two rows of Table 2 show that the coefficient estimates imply that a change in delta from its 25 th to its 75 th percentile is associated with an increase in the probability of failure of between 0.01 and 0.08 if leverage is at its 25 th percentile, and a larger increase between 0.05 and 0.23 if leverage is at its 75 th percentile, with the difference in the effect of the change of delta between the high- and low-leverage scenarios being in the range from 0.035 (column 5) to 0.177 (column 7). The magnitudes of these changes are large, as can be seen by comparing them with the unconditional probability of failure, which ranges from 0.12 to 0.15 across subsamples. In contrast, the estimated coefficients for vega are small in magnitude, not statistically significant, and change signs across specifications (even if, in results reported in the Online Appendix, we restrict the sample to the subsample included in all specifications). Only one control variable is statistically different from zero in at least one specification (the variable that captures the share ownership of institutional blockholders) and most estimated coefficients (with the exception of the coefficients of the share ownership of institutional blockholders and of the CEO's tenure in the company) are small in magnitude, implying changes in the probability of failure associated with a change in the variable from its 25 th to its 75 th percentile of less than three percent (in absolute value). ${ }^{33}$

32 Because of the very large number of potential controls and the limited sample size, we do not estimate a specification including all controls. Following Belloni et al. (2014), we select controls that are either correlated with the dependent variable or the explanatory variables of interest, so as to minimize the potential omitted variable bias, and that have few missing values. To check the robustness of our results to different sets of controls, in the Online Appendix, we report several alternative choices of the set of controls.

33 An exception is the estimation in column 7, whose sample contains only bank holding companies. For this specification, the coefficient estimates for firm size, the dummy for 
We emphasize that our results do not support the hypotheses that shareholder-manager conflict and weak governance explain the relation between compensation incentives and risk or are, otherwise, responsible for the different levels of risk taking among the firms in our sample. First, the coefficients of delta and its interaction with leverage are barely affected by the inclusion of governance variables. Second, we find no significant relation between governance variables and risk, with the exception of the share ownership of institutional blockholders in the last specification. Moreover, we find that a higher share ownership by institutional blockholders, which is usually interpreted as implying a better monitoring of the CEO by shareholders, actually increases risk, although the coefficient is statistically significant only at the $10 \%$ significance level.

We note that Bennett et al. (2015) find a negative relation between inside debt and bank risk. Our results may differ from theirs in that they include a set of controls to account for bank risk, such as non-performing loans, loan loss reserves, or brokered deposits, so they estimate the residual effect of compensation incentives after controlling for these variables. ${ }^{34}$ Brown et al. (2015) find a positive relation between termination payments and bank risk, but they measure risk prior to the crisis. ${ }^{35}$

\subsection{Investment Banks and Other Non-Bank Firms}

Our sample includes the five major pre-crisis investment banks (Bear Stearns, Goldman Sachs, Lehman Brothers, Merrill Lynch, and Morgan Stanley) and four other firms whose main business is brokerage and investment banking (even if they own depositary subsidiaries). These investment banking firms exhibit very large values of delta (of the five largest values of delta in the sample, four, including the maximum, correspond to investment banks) and leverage, as well as a high failure rate (three out of the nine investment banking firms fail). Therefore, the presence of investment banks in the sample may exert a large influence over the estimated coefficients. In addition to investment banks, the sample also contains firms specialized in investment advice (such as Franklin Resources or T. Rowe Price) and retail brokerage (such as Charles Schwab). Apart from having a very different business model and capital structure, some of these firms have very large values of delta (notably Charles Schwab, in which the founder and CEO in year 2006 holds a very large ownership stake), which, again, could have a large influence on the estimated coefficients. Irrespectively of these econometric concerns, it is important to understand whether our results are due solely to differences between these subgroups of financial firms and the rest of the financial firms in the sample, whose main activity has to do with lending, or whether the relation between delta and failure also holds within the latter group of financial firms. In particular, risk-taking incentives may be different for bank holding

international presence, and the dummy for the control of more than one bank imply changes in the probability of failure of between 0.07 and 0.15 when the corresponding variable changes from its 25 th to its 75 th percentile. For comparison, for this specification, the change in the probability of failure when delta changes from its 25 th to its 75 th percentile is 0.23 when leverage is at its 75 th percentile.

34 Their sample is different form ours, since it is composed solely of bank holding companies. However, if we estimate the specification in column 4 of Table 2 for the subsample of bank holding companies, the coefficient of inside debt is still not statistically significant. 35 However, Muscarella and Zhao (2015) find a negative relation between termination payments and firm risk in S\&P 500 firms. 
companies, whose funding stems mostly from guaranteed deposits and which, because of their key role within the payment system, may be more likely to be bailed out than other financial institutions. Therefore, in columns 1 and 2 of Table 3 we report the results of estimating model (3) with dummies for the different subsectors of financial firms in the sample: commercial banks (SIC code 602); savings institutions (SIC code 603); personal credit institutions (SIC code 6141); mortgage bankers and loan correspondents (SIC code 6162); security brokers, dealers, and flotation companies (SIC code 6211); and investment advice (SIC code 6282). ${ }^{36}$ Including these subsector dummies affects the magnitude of the coefficients for delta, leverage, and vega (as compared to the ones reported in columns 2 and 8 of Table 2), but they are all not significantly different from zero. However, the coefficients for the interaction between delta and leverage and their statistical significance are unaffected by the inclusion of subsector dummies. In columns 3 to 6 of Table 3 we further explore the influence of subsector heterogeneity by excluding investment banks and investment advice firms (in columns 3 and 4) and by, in addition to excluding those firms, focusing only on bank holding companies (in columns 4 and 5). ${ }^{37}$ Excluding investment banks and investment advice firms, or considering only bank holding companies, leads to a large and negative coefficient of delta and a large and positive coefficient of its interaction with leverage, coefficients that are very similar regardless of whether we include no controls or the full set of controls. ${ }^{38}$ These results help explain the difference between the coefficients in columns 3, 4, and 7 in Table 2 and in the other columns of that table, since the subsamples that we use to estimate our model with termination payments or inside debt as controls do not include a large fraction of investment banks because of data availability, and the subsample in column 7 does not contain any investment bank. ${ }^{39}$

$\overline{36}$ In the sample, there are firms in 8 different 4-digit SIC codes as of December 2016, but one SIC code (6199) contains only one firm (Citigroup), which has a 6020 SIC code in other years, so we merge this firm with the subsector of commercial banks (which contains the other large bank holding companies). We also merge the SIC codes 6035 and 6036, which differ only in whether they are federally charted.

37 We note that the distinction between bank holding companies and other firms is not done on the basis of their SIC code. A firm is a bank holding company, and, as such, is supervised by the Federal Reserve, if it controls one or more commercial banks. Although most bank holding companies in our sample have SIC code 602 (corresponding to commercial banks), a few have other SIC codes. None of the investment banks is a bank holding company as of year 2006, but two bank holding companies (which are excluded from the sample in columns 4 and 5) have SIC code 6282 (Investment Advice).

38 To understand why these coefficients are larger in magnitude than the corresponding coefficients reported in Table 2, it is important to notice that our dependent variable is a dummy variable, so it is bounded between 0 and 1 . Therefore, if there are failed firms (that is, firms with the maximum value of the dependent variable) with very high values of the interaction between delta and leverage (such as the failed investment banks), the estimated coefficient of the interaction term will tend to be low, to minimize the extent to which predicted values of the dependent variable exceed 1 for high values of the interaction term or fall below 0 for low values of the interaction term.

39 As we note in Section 3., delta and vega are computed differently for four investment banks, because we have less precise information about the option holdings of these banks' CEOs. Therefore, excluding investment banks greatly reduces the potential impact on our results of having firms whose delta and vega is computed differently. In fact, if one 
Therefore, the estimated relation between delta, leverage, and bank failure holds even more strongly as we narrow down the sample to more bank-like financial firms.

\subsection{Too-Big-To-Fail Institutions}

We identify as failed those firms that either close or are acquired with the intervention of bank supervisors. However, there may be distressed financial institutions that supervisors would not allow to fail, but that are too large to find a suitable acquirer. These financial institutions may, thus, not be part of our list of failed institutions, even if they took on large risks ex ante and experienced strongly negative outcomes as a result of those risks. This possibility may bias our estimates towards zero if the risk-taking incentives of the firms that are both too-big-to-fail and too-big-to-be-acquired are strong and if these firms took on large risks. On the other hand, it may lead us to overestimate the relation between risk-taking incentives and bank risk if large banks take on large risks yet, for some reason, opt for compensation arrangements with low values of delta.

We take two approaches to evaluate the potential biases generated by too-big-to-fail institutions. First, following Fahlenbrach et al. (2012), we consider Citigroup and Bank of America as failed, given the massive amount of aid they received from the government. The estimation results (reported in the Online Appendix) are identical to those in Table 2. Second, we identify the banks in the sample that could be considered both too-bigto-fail and too-big-to-be-acquired, which we label TBTF banks. We use two definitions of TBTF. First, we use the total assets as of December 2006 of the smallest institution (Keycorp) included in the 2009 Supervisory Capital Assessment Program (the stress test) as the threshold to determine whether a firm is TBTF, since the inclusion of a firm in the 2009 stress test can be taken as a signal that regulators deemed the firm to be of systemic importance. With this definition, we identify 25 firms as TBTF. The problem with this definition is that seven out of the "TBTF" firms actually fail during the crisis (according to our definition of failure). Therefore, we use as well an alternative definition of "revealed" TBTF: We identify as revealed-TBTF those firms with total assets as of December 2006 that are larger than those of the largest failed institution in our sample (Merrill Lynch). This criterion results in a set of four revealed-TBTF firms: Citigroup, Bank of America, JPMorgan Chase, and Goldman Sachs. ${ }^{40}$ A comparison of columns 1 to 4 in Table 4 and columns 2 and 8 in Table 2 (which contain the results of the baseline specifications) shows that including a dummy variable to identify TBTF firms does not significantly affect the estimated coefficients of delta and its interaction with leverage. In the subsample of

excludes from the sample these four investment banks, as well as those firms for which we use information from year 2005 to compute delta and vega, and then re-estimates the specifications reported in columns 2 and 8 in Table 2 , the results are very similar to those reported in columns 3 and 4 in Table 3 (which are obtained excluding investment banks and investment advice firms from the sample).

40 If size is measured by market capitalization as of December 2006, the largest failed institution is Wachovia, and the TBTF institutions are Citigroup, Bank of America, JPMorgan Chase, and Wells Fargo. Using the definition of revealed-TBTF based on market capitalization leads to results identical to the ones we report for the asset-based definition. 
bank holding companies, the inclusion of the too-big-to-fail dummies slightly increases the magnitude of the coefficients of delta and its interaction with leverage. ${ }^{41}$

\subsection{Specification}

The high positive skewness of delta and of its interaction with leverage and, to a lesser extent, of other compensation variables, motivates including their logarithmic transformations in the estimating equation. To check the sensitivity of the results to this transformation, we report in columns 1 and 2 of Table 5 the results of estimating model (3) with the untransformed compensation variables. In columns 3 through 6 , we also report the results of estimating probit and logit models instead of a linear probability model. Since testing for the presence of interaction effects in non-linear models is problematic (Greene, 2010), we focus on checking whether the estimated changes in the probability of failure associated with changes in delta for different values of leverage are consistent across specifications. In all cases, a change in delta from the 25 th to the 75 th percentile is associated with a negative or positive and small change in the probability of failure if leverage is at its 25 th percentile, whereas the change is larger (between 1 and 5 percentage points higher, depending on the specification) and positive if leverage is at its 75 th percentile. The differences between the estimated changes in the probability of failure for low and high levels of leverage are very similar to the ones reported at the bottom of columns 2 and 8 in Table 2, except for the linear model with untransformed variables, in which the difference is smaller. ${ }^{42}$

We note that the coefficient of delta is negative in all the specifications reported in columns 2 to 8 in Table 2 and in all the specifications reported in tables 3,4 , and 5 , and the coefficient of the interaction between delta and leverage is positive and statistically significant (at least at the $10 \%$ level) in all specifications. Therefore, our main results are largely robust to the choice of control variables, sample (since different specifications are estimated with different subsamples, because of data availability), and functional form.

\subsection{Risk vs. Poor Management}

A possible concern about the use of failure as a measure of risk is that it may capture poor management rather than risk. If failure reflects poor management, the results in previous sections may capture the correlation between persistent firm or managerial quality, delta, and leverage. To address these concerns, we include measures of pre-crisis profitability as controls. If failure during the crisis is due to persistent poor management, the estimated

\footnotetext{
$\overline{41}$ If, instead of including a dummy variable, we exclude from the sample the TBTF firms (according to either definition), estimated coefficients barely change with respect to those reported in Table 2. The standard errors of the coefficients are higher, however, if we exclude the firms identified as TBTF using the stress test definition, which is to be expected given that excluding these firms significantly reduces the sample's size and takes away 7 out of the 19 firms that fail during the sample period.

42 We also estimate the baseline model (in logs) without winsorizing the compensation variables or winsorizing them at different percentiles. We also include the natural logarithm of leverage instead of leverage to account for a possibly diminishing effect of leverage on failure. In all cases, the results (reported in the Online Appendix) barely change relative to the ones presented in Table 2 .
} 
coefficient of the pre-crisis profitability measure will be negative. Moreover, if the correlation between persistent firm quality, leverage and delta is driving the results, including pre-crisis profitability as a control may reduce the magnitude and statistical significance of the coefficients for delta and its interaction with leverage. To measure pre-crisis profitability we use the market-to-book ratio of equity as of December 2006, average ROA in the period 2004-2006, and average stock returns in the same period, although we note that all these variables could also be proxies of firm risk. The results in Table 6 show that the coefficients of the market-to-book ratio and of stock returns in one of the specifications are negative (although small and not statistically significant at conventional significance levels), whereas the coefficients of both ROA and of stock returns in one of the specifications are positive (although only statistically significant, at the $10 \%$ level, in the case of average ROA). At the same time, the coefficients of delta and its interaction with leverage barely change with respect to those reported in Table 2 . Taken together, these results do not support the hypotheses that the relation between delta, leverage, and failure is due to the correlation of these variables with persistent profitability. If anything, the coefficients of ROA suggest that failed banks had higher profitability prior to the crisis.

\subsection{Alternative Risk Measures}

The results in previous sections show that a larger delta in highly levered firms is associated with a higher probability of failure. In this section, we check whether a similar relation between delta, leverage, and risk is obtained if we use other measures of firm risk computed during the crisis period. First, we use the measure of the distance to default proposed by Bharath and Shumway (2008), and the corresponding expected default frequency, as alternative, continuous measures of the probability of failure. Second, for comparison with previous work, we also use the volatility of stock returns, the market beta of the firm's stock (as in Cheng et al., 2015, or DeYoung et al., 2013) and the buy-and-hold returns of the firm's stock (Fahlenbrach and Stulz, 2011).

Merton's (1974) distance-to-default (DD) measures the distance of the expected log asset value to the log value of the firm's liabilities, scaled by the volatility of the log asset value. Bharath and Shumway (2008) propose a "naïve" DD measure with the same functional form as the one obtained from Merton's (1974) model, but in which some variables (namely, the value and volatility of the firm's assets) are approximated instead of being obtained as solutions of the model. In addition to its simplicity, Bharath and Shumway (2008) show that this measure outperforms the model-implied Merton's DD in forecasting firm failure. Under the assumptions of the Merton's model, one can compute the expected default frequency $(\mathrm{EDF})$ as $\Phi(-D D)$, where $\Phi$ is the standard normal distribution function. ${ }^{43}$

We compute DD and EDF yearly and then aggregate the yearly measures into a single measure for the 2007-2010 period. Because of attrition during the crisis, a simple average of the yearly measures may overestimate (underestimate) DD (EDF) for the firms that fail early during the crisis period, since the average DD (EDF) for these firms is computed over a relatively benign period, whereas the average for the surviving firms is computed also over the latter part of the crisis period, in which the values of DD (EDF) are generally lower (higher). Therefore, we compute the average values over the 2007-2010 period, but in the

$\overline{43}$ In the Online Appendix, we describe in detail the formula and data used to compute Bharath and Shumway's (2008) DD and EDF. 
calculation of these averages, we impute a DD (EDF) equal to 0 (1) to failed firms in the years after their failure. ${ }^{44}$ In Table 7 , we report the results of estimating equation (3) with DD or EDF as the dependent variable instead of Failed. In the case of EDF, we estimate a Tobit model in which we replace the dependent variable by one for failed firms, because the EDF measure is bounded above by one and its value for failed firms is negligibly different from one. We note that a positive coefficient implies that risk is decreasing in the corresponding variable if DD is the dependent variable, whereas it implies that risk is increasing in the corresponding variable if EDF is the dependent variable. Consistently with the results we obtain with Failed as the dependent variable, the coefficient of delta is positive (negative) and the coefficient of the interaction term is negative (positive) in the specifications with DD (EDF) as the dependent variable, although increases in delta decrease $\mathrm{DD}$, or increase EDF, only for values of leverage above the 75 th percentile (but still in the range of values of leverage in the sample). We note that, in contrast to the results with Failed as the dependent variable, the coefficient of vega is statistically significant in some specifications, in which a higher vega is associated with lower risk, as measured by a higher DD.

Following Fahlenbrach and Stulz (2011), we also measure risk using the volatility of stock returns, beta, and buy-and-hold returns computed over the period from July 1, 2007 , to December 31, 2008. This period essentially coincides with a period of continuously falling stock prices in the financial sector, which extends from June 2007 to March 2009, so greater priced risk should result in lower returns during the period. Extending the measurement period into 2009 would be unlikely to capture news about risk taking prior to the crisis and would capture, instead, the effects of actions taken by banks during the crisis (whereas our measure of incentives captures CEO incentives prior to the crisis). As argued by Fahlenbrach and Stulz (2011), returns in later parts of the crisis may also reflect to a large extent news about regulators' actions, rather than news about CEOs' decisions about risk taken prior to the crisis.

Columns 1 to 3 in Table 8 show that, for the three risk measures, a higher delta translates into higher risk (note that lower buy-and-hold returns imply higher ex ante risk taking) for high levels of leverage but not so (or to a lesser extent) for low levels of leverage. However, the magnitude of the difference between the effect on risk of a higher delta if leverage is high and the effect if leverage is low is smaller than if risk is measured by the estimated probability of failure. ${ }^{45}$ Moreover, the coefficient of the interaction term is statistically significant (at the $10 \%$ level) only for beta. Therefore, the results are broadly consistent with, but weaker than, the ones we obtain if we use failure or DD to measure risk.

A possible explanation for the weaker results obtained when we use buy-and-hold returns to measure risk is that, because of limited liability, returns are bounded below at -1 . If we let $y^{*}$ denote the expected discounted sum of expected cash flows net of debt claims, higher risk taking prior to the crisis is likely to lead to negative, and possibly large, values of $y^{*}$ during the crisis. However, because of limited liability, the stock price $y$ is equal to

$\overline{44}$ We note, however, the results barely change if we simply use the average or the minimum (maximum) value of DD (EDF) as measures of default risk during the crisis period. 45 One can evaluate this magnitude by comparing the predicted changes in the dependent variable reported at the bottom of Table 8 with the average of the dependent variable. Comparing those changes with the sample standard deviation of the dependent variable (not reported) leads to a similar conclusion. 
$\max \left\{y^{*}, 0\right\}$. Thus, the stock price (and, as a result, stock returns as well) is a left-censored variable, which leads to biased coefficients if model (3) is estimated using OLS. In normal periods, the left-censoring of returns may not be a concern, but returns during the crisis are effectively -1 for a significant fraction of stocks in our sample (for example, six stocks have returns lower than -0.99 and fourteen stocks have returns below -0.9 ), so the bias may be significant. ${ }^{46}$ To deal with this potential bias, we replace the returns of failed firms by -1 and estimate a Tobit version of model (3) ${ }^{47}$ The Tobit estimates, which we report in column 4 of Table 8 are more in line with the ones we obtain when we measure risk using failure or DD.

Another reason why the results for buy-and-hold returns and DD may differ is that stock returns incorporate the expectation of bailouts or, in general, government support of the financial sector. Because of banks' role in the payment system and because of the costs of resolving insured depository institutions, bailout expectations may affect the returns of banks more than those of other financial institutions, such as mortgage lenders not financed mainly through deposits, brokerage firms, or asset managers. Therefore, we also reestimate the specification with buy-and-hold returns as the dependent variable for the subsample of bank holding companies. As in the cases in which we use Failed or DD as dependent variables, the results, which we report in column 5 of Table 8, are stronger and highly statistically significant if we restrict the sample to bank holding companies. ${ }^{48}$

\subsection{Incentives and Risk Before and After the Financial Crisis}

One would like to know whether the relation between delta, leverage, and risk that we document in the previous sections is a phenomenon specific to the particular period immediately preceding the crisis. However, it is not possible to implement our empirical strategy in other periods. The financial crisis is a unique laboratory to analyze the relation between incentives and firm risk, because it is a realization of a negative tail shock affecting the whole financial industry. Therefore, failure during the crisis can capture firms' exposure to aggregate tail risks, which is very difficult to measure in good times. From a purely econometric point of view, the financial crisis is also the only period since year 1993 (when regulatory reforms made it possible to compute delta and vega for the CEOs of listed firms) in which there is a substantial incidence of firm failure among the relatively large listed financial firms for which we have compensation information. In other periods, there are too few failures among these firms to use realized failure as a measure of risk taking.

To shed light on the relation between compensation incentives, leverage and the risk of bank failure in other periods, we replace the failure dummy variable with the alternative

46 Moreover, our measure of buy-and-hold-returns is likely to overestimate the returns of failed firms because to compute buy-and-hold returns for failed firms we effectively assume that the final proceeds to equity holders, computed using reported delisting returns, are invested until December 31, 2008, in a risk-free deposit with a zero return. Therefore, the returns of failed stocks post failure are significantly larger than those of even relatively healthy financial institutions, which experience negative returns throughout the period.

47 We note that 12 out of 19 failed firms have returns below -0.9 and only 2 have returns above -0.7 . We also note that we obtain essentially the same results if we also replace the returns of surviving firms with buy-and-hold returns lower than -0.9 by -1 .

48 We note that results are similar or stronger if we estimate a Tobit model, if we include the too-big-too-fail dummies, or if we exclude too-big-to-fail banks from the sample. 
measures of default risk (DD and EDF) introduced in Section 5.6 and re-estimate the main regressions for the four-year periods from 2003 to 2006 and from 2011 to 2014. The results, which we report in Table 9, are significantly weaker, but mostly in line with the ones we obtain with these measures during the financial crisis. Thus, the coefficients of delta and of its interaction with leverage have the same signs as the ones in Table 7 , with the exception of the coefficients in column 3, which are essentially zero. However, the coefficients of the interaction term tend to be smaller in magnitude and they are not statistically significant in some specifications. ${ }^{49}$ A possible interpretation of these results is that the relation between delta, leverage and risk is not particular to the period immediately preceding the crisis, but is weaker in other periods. However, an alternative interpretation of the weaker relation between incentives and the risk measures is that these measures fail to capture in normal times firms' exposure to aggregate tail risks, such as a significant drop in housing prices.

\section{Discussion of the Results}

Endogeneity of Compensation and Interpretation of the Results. Our results are consistent with the theoretical argument that the effect of delta on CEOs' incentives to take on risk depends on bank leverage: Whereas a higher delta provides weak incentives, or a disincentive, to take on risk in firms with low leverage, a higher delta provides incentives for risk taking in highly levered firms. However, delta may be endogenous, since it may be correlated with unobserved determinants of CEO risk-taking incentives or firm risk. Therefore, we also consider alternative, non-causal interpretation of our results.

First, delta may be related to other governance or compensation features that influence CEOs' risk-taking incentives or constrain CEOs' ability to manage risk. To account for the influence of these factors, we include control variables that proxy for governance features (GIM index, E-index, board size, board independence, CEO duality, the percentage of independent directors elected after the CEO was appointed, institutional ownership) and the strength of other potential incentives (inside debt, total pay, CEO age, termination payments). Including these control variables does not alter the sign or magnitude of the estimated coefficients of delta and its interaction with leverage, which suggests that these coefficients are not capturing the relation between delta and risk-taking incentives other than those created by equity compensation. ${ }^{50}$ However, our control variables are noisy proxies of the incentives and constraints faced by CEOs when determining firm risk, so our coefficient estimates could still be capturing the fact that some unobserved risk-taking incentives are stronger in firms with both high leverage and high delta.

Second, the assignment of compensation contracts to CEOs may not be orthogonal to banks' inherent or target riskiness. Thus, our results could be due to the fact that firm risk determines CEO compensation, instead of reflecting a causal effect of compensation on risk via the CEO's risk-taking incentives. In standard principal-agent models, the performance

\footnotetext{
49 We report specifications with average DD and EDF as dependent variables, because attrition is not a significant problem during these periods. Results do not change qualitatively if we replace average DD and EDF by the minimum DD and the maximum EDF during the period, respectively.

50 Recall that the differences across specifications in the estimated coefficients of interest are largely due to whether investment banks are included in the sample.
} 
sensitivity of pay should be, other things equal, negatively correlated with firm risk, since the cost of linking pay to performance (in terms of a higher risk premium that has to be paid to the CEO) is higher for firms with more volatile performance. ${ }^{51}$ However, as argued by Prendergast (2002), greater risk may be correlated with the need to grant greater discretion to the CEO or with a higher value of his effort, which may call for a higher pay-performance sensitivity to elicit better decisions or greater effort from the CEO. In line with these arguments, Cheng et al. (2015) propose that banks that are inherently riskier (which would make a low sensitivity of pay to performance optimal) are also banks in which the marginal return of CEO effort is higher (which would make a high pay-performance sensitivity optimal). If the relation between riskiness and the marginal productivity of CEO effort were positive and strong enough, the CEOs of riskier firms would not have significantly lower deltas and could even have higher deltas. Therefore, an explanation of our results along the lines of the one provided by Cheng et al. (2015) would be that the marginal return of CEO effort or the degree of CEO discretion is strongly correlated with firms' inherent riskiness in highly levered firms, but less so in less levered firms. Further work is needed to assess the plausibility of these hypotheses, although we note that controlling for CEO discretion does not affect our results.

An alternative, non-causal, explanation of our results is that riskier firms seek more risk-tolerant CEOs, either because it is less costly for risky firms to hire risk-tolerant CEOs (which require a lower compensation for their exposure to firm risk) or because more risk-tolerant CEOs are more likely to implement the desired risky policies. As a result, riskier firms may offer contracts with greater pay-performance sensitivity, since these contracts may be more attractive for CEOs with greater risk tolerance (Ackerberg and Botticini, 2002). Although we include CEO age and CEO wealth to control for risk tolerance, these variables may capture only part of the differences in risk tolerance across CEOs, so our results could be explained by the matching of risk-tolerant CEOs with firms with high leverage and delta. However, an explanation along these lines would require that riskier firms - conditionally on leverage - seek risk-tolerant CEOs if they are highly levered, but not if they have low leverage, or that the value of a high-delta contract for a risk-tolerant $\mathrm{CEO}$ is high (relative to the value of the contract for a less risk-tolerant CEO) if the firm is highly levered but not if it has low leverage.

Policy Implications. Our empirical analysis cannot directly address the question as to whether compensation incentives led to socially inefficient levels of risk at U.S. financial institutions and, thus, cannot determine whether regulating the pay of bank executives is socially optimal. However, our results do contribute to the policy debate about the regulation of pay in financial firms in several ways. First, we show, in contrast to some previous results, that CEO compensation incentives at U.S. financial firms are related to the risk of failure during the financial crisis. The broad policy implication of this evidence is that there may be a rationale for regulating pay in order to control risk at financial institutions. Second, we show that high risk is associated with a combination of high exposure of the CEO's wealth to his firm's equity (delta) and high leverage. Stock options grants contribute to risk taking incentives through their effect on delta but not vega. According to our results, the sensitivity of option value to stock return volatility (vega) is not related to firm risk. Therefore, our results have the more concrete policy implications that: a) limiting option compensation may not be an effective tool to limit risk-taking

\footnotetext{
51 See Prendergast (2002) for a discussion of the standard models and the empirical
} evidence relative to the relation between risk and incentives. 
incentives; b) regulators should focus on the CEO's overall equity exposure (delta); and c) the limits to delta should depend on the firm's leverage. We note that these policy implications apply if the effect of delta on risk that we uncover is causal. However, even if the effect were not causal, limiting delta could still reduce firm risk either by making it more costly for riskier firms to compensate their CEOs for their risk exposure (since risky firms would not be able to offer the cost-minimizing contract to their CEOs) or by not allowing financial firms to attract the more risk-tolerant managers.

We also note that the policy implications of our results apply to contexts in which the delta of bank executives is high. Thus, it is an open question whether these implications also hold in countries in which the delta of bank CEOs is low. For example, although the evidence about executive compensation in Europe is much more limited, it appears that the equity exposure of the CEOs of the large European banks prior to the crisis was lower than that of their U.S. counterparts (Ayadi et al., 2012; Murphy, 2013; Vallascas and Hagendorff, 2013; Uhde, 2016). Limiting delta could be an ineffective tool to reduce risk in such a context.

An additional consideration in designing pay regulation is that limiting delta in highly levered banks could have unintended consequences. First, the reduction in risk achieved by limiting delta may come at the cost of providing CEOs with weaker incentives to find or implement positive NPV projects. Second, the impact that such regulation may have on banks' leverage choices needs to be better understood. For example, to the extent that CEOs cannot substitute fixed pay for equity pay, CEOs may have an incentive to reduce leverage so as to circumvent or reduce limitations on equity pay. However, predicting the effect that leverage-dependent constraints on compensation may have on leverage is difficult, since the interaction of compensation and leverage decisions is complex and our theoretical understanding of their joint determination is still limited. ${ }^{52}$

To limit delta, regulators could use explicit caps on delta conditional on leverage or penalize a higher delta more strongly for higher levels of leverage. For example, recent E.U. regulations (as established by the Directive 2013/36/EU, known as the Capital Requirements Directive IV) that set a maximum ratio of variable to fixed pay penalize delta by forcing financial institutions to increase the fixed component of pay if they want to increase the CEO's equity exposure. Making the maximum ratio of variable to fixed compensation decrease with leverage would make the penalty from using delta increase with leverage. To limit the unintended consequences of one-size-fits-all constraints, the constraints on delta could be alternatively implemented through the supervisory process. Thus, supervisors may be instructed to consider a high delta as unsafe if a bank is highly levered and to demand a reduction in delta in such a case, but be allowed room to exercise their discretion as to the need for and the magnitude of the reduction. The implementation

52 The few existing models of the joint determination of managerial compensation and leverage make very different assumptions about who holds control rights over leverage and compensation (the manager or shareholders), about the influence of the manager's choices on asset risk, and about the nature of the agency problem between shareholders and managers, and, in most cases, impose very strong constraints on the form of the manager's compensation, such as assuming that the manager's pay consists solely of equity (Morellec, 2004; Cadenillas et al., 2004; Lewellen, 2006; Carlson and Lazrak, 2010; Morellec et al., 2012). Moreover, the relation between leverage and compensation derived from these models is often non-monotonic and obtained numerically. Thus, it is difficult to predict how constraints on compensation may affect equilibrium compensation and leverage. 
of the constraints to delta through the supervisory process could, however, be limited by supervisory resources or capture.

Vega. Whereas our results show that delta is associated with bank risk, they also show that vega, which is the most common measure of risk-taking incentives employed in prior work, is not associated with bank failure during the crisis. Although vega has important limitations as a measure of risk-taking incentives, prior work has often found vega to be related to firm risk. In particular, DeYoung et al. (2013) find a positive relation between vega and firm risk (measured by means of beta, stock return volatility, or idiosyncratic volatility), but they measure risk prior to the crisis, and Gande and Kalpathy (2015) find vega to be associated with the extent of U.S. Federal Reserve emergency loans during the crisis. The absence of an association between vega and bank failure in our sample could be due to the facts that there is greater variation in delta than in vega in the sample, that there is a positive correlation between both variables (and between either one and leverage), and that the effect of delta on incentives is stronger than the one stemming from vega. Under these circumstances, it may be difficult to capture the effect of vega in a sample of moderate size.

Our combined results about the relation between bank risk, delta, and vega suggest that the strong trend among financial firms, initiated in the early 2000 s, of replacing stock option compensation by restricted stock may not, by itself, significantly alter the risktaking incentives of bank CEOs. Our evidence also suggests that regulatory restrictions on the use of stock options may have a limited impact on the risk-taking incentives of bank CEOs.

Relation to Valuation Models of the Risk-Taking Incentives of Equity. As mentioned in the introduction, Chesney et al. (2012) and Anderson and Core (2015) provide valuation models to compute the derivative of the market value of equity (modeled as an option on firm value) with respect to changes in the volatility of firm value. Further, Chesney et al. (2012) find a positive association between their measure of the sensitivity of CEO wealth to asset value volatility and banks' asset write-downs during the financial crisis. ${ }^{53}$ The approach of Chesney et al. (2012) and Anderson and Core (2015) has the advantage that it allows them to provide a dollar measure of the risk-taking incentives stemming from the limited liability of equity. However, their approach has the drawback that, on top of the well-known problems of using the market value of options as a measure of CEOs' expected utility (Lambert et al., 1991; Ross, 2004; Ingersoll, 2006; Lewellen, 2006), obtaining the value of equity as a call option on firm value requires making very strong assumptions about, among other things, banks' capital structure, the tradeability of assets, or the stochastic properties of the value of banks' assets (Nagel and Purnanandam, 2015). These strong assumptions, together with the approximations made to measure the variables in the theoretical model, imply that the quantitative measures of risk-taking incentives derived from these models are likely to exhibit a large measurement error, especially given that the incentive measures are highly nonlinear in their arguments. ${ }^{54} \mathrm{We}$ believe that the valuation approach of Chesney et al. (2012) and Anderson and Core (2015) and our reduced-form approach are complementary.

$\overline{53}$ We note that Guay (1999) proposes an approximation to the sensitivity of equity value to volatility and finds that this sensitivity is generally very small for a sample of U.S. CEOs in 1993, consistently with a generally small leverage in that sample.

54 We note that the computation of delta relies on minimal assumptions about the valuation of stock options and that, in fact, a large component of delta, consists simply of the market value of the CEO's stock holdings, as one can see in expression (1). 


\section{Conclusion}

Increasing the exposure of a risk-averse, undiversified CEO to his firm's stock price may provide the CEO incentives to reduce the firm's risk. However, in highly levered firms, shareholders have strong incentives to shift risk to debtholders. Therefore, in these firms, a greater exposure to the firm's stock price, by aligning the CEO's incentives with those of shareholders, may increase the CEO's risk-taking incentives.

Using a sample of large U.S. financial firms we find support for this hypothesis: A higher pre-crisis sensitivity of CEO wealth to stock price (delta) is associated with a significantly (quantitatively and statistically) higher probability of failure during the 20072010 financial crisis in highly levered firms. However, a higher delta is not associated with a higher probability of failure in firms with relatively low leverage.

We make several contributions to the debate about the relation between executive compensation and risk in financial firms. First, we show that the risk-taking incentives generated by CEOs' stock and option compensation are associated with risk in financial firms, in contrast with some of the results in previous literature. Second, we provide evidence that the relevant source of risk-taking incentives for the CEOs of large financial firms prior to the crisis was their exposure to their firms' stock returns. We find no evidence that the incentives to increase stock return volatility that may have been created by CEOs' stock option holdings were associated with a higher probability of failure. Therefore, our results suggest that the stronger risk-taking incentives of the CEOs of some financial firms were not the result of a misalignment between CEOs' and shareholders' incentives in those firms. Instead, a better alignment between CEOs' and shareholder incentives seems to have encouraged CEOs to shift risk to debtholders and depositors. Our results also have the implication that banking supervisors should consider compensation arrangements in relation to leverage when they evaluate the risk-taking incentives created by executive compensation. Finally, by establishing a link between CEO compensation and risk in financial firms, our results suggest that regulating CEO compensation in financial firms may have an impact on risk, but that simply replacing stock options with stock may not reduce risk. 


\section{References}

Ackerberg, D. A. and Botticini, M. (2002) Endogenous matching and the empirical determinants of contract form, Journal of Political Economy 110, 564-591.

Anderson, J. D. and Core, J. E. (2015) Managerial incentives to increase firm volatility provided by debt, stock, and options, SSRN Scholarly Paper ID 2115093, Social Science Research Network, Rochester, NY.

Ayadi, R., Arbak, E., and De Groen, W. P. (2012) Executive compensation and risktaking in European banking, in Barth, J. R., Lin, C., and Wihlborg, C. (editors), Research Handbook on International Banking and Governance, chapter 8, Edward Elgar Publishing, 179-199.

Bebchuk, L., Cohen, A., and Ferrell, A. (2009) What matters in corporate governance?, Review of Financial Studies 22, 783-827.

Bebchuk, L., Cohen, A., and Spamann, H. (2010) The wages of failure: Executive compensation at Bear Stearns and Lehman 2000-2008, Yale Journal on Regulation 27, 257-282. Bebchuk, L. and Spamann, H. (2010) Regulating bankers pay, Georgetown Law Journal 98, 247-287.

Bebchuk, L. A. and Fried, J. M. (2004) Pay without performance, Harvard University Press Cambridge, MA.

Belloni, A., Chernozhukov, V., and Hansen, C. (2014) High-dimensional methods and inference on structural and treatment effects, The Journal of Economic Perspectives 28, $29-50$.

Bennett, R. L., Gntay, L., and Unal, H. (2015) Inside debt, bank default risk, and performance during the crisis, Journal of Financial Intermediation 24, 487-513.

Bhagat, S. and Bolton, B. (2014) Financial crisis and bank executive incentive compensation, Journal of Corporate Finance 25, 313-341.

Bharath, S. and Shumway, T. (2008) Forecasting default with the Merton distance to default model, Review of Financial Studies 21, 1339-1369.

Black, F. and Scholes, M. (1973) The pricing of options and corporate liabilities, Journal of Political Economy 81, 637-654.

Breeden, D. and Viswanathan, S. (1998) Why do firms hedge? An asymmetric information model, Working Paper, Fuqua School of Business.

Brockman, P., Martin, X., and Unlu, E. (2010) Executive compensation and the maturity structure of corporate debt, The Journal of Finance 65, 1123-1161.

Brown, K., Jha, R., and Pacharn, P. (2015) Ex ante CEO severance pay and risk-taking in the financial services sector, Journal of Banking and Finance 59, 111-126.

Burkart, M., Gromb, D., and Panunzi, F. (1997) Large shareholders, monitoring, and the value of the firm, The Quarterly Journal of Economics 112, 693-728.

Cadenillas, A., Cvitanić, J., and Zapatero, F. (2004) Leverage decision and manager compensation with choice of effort and volatility, Journal of Financial Economics 73, 71-92. Carlson, M. and Lazrak, A. (2010) Leverage choice and credit spreads when managers risk shift, The Journal of Finance 65, 2323-2362.

Cassell, C. A., Huang, S. X., Manuel Sanchez, J., and Stuart, M. D. (2012) Seeking safety: The relation between CEO inside debt holdings and the riskiness of firm investment and financial policies, Journal of Financial Economics 103, 588-610.

Cheng, H., Hong, H., and Scheinkman, J. (2015) Yesterday's heroes: Compensation and creative risk-taking, The Journal of Finance 70, 839-879. 
Chesney, M., Stromberg, J., and Wagner, A. (2012) Risk-taking incentives, governance, and losses in the financial crisis, Research Paper No. 10-18, Swiss Finance Institute.

Coles, J. L., Daniel, N. D., and Naveen, L. (2006) Managerial incentives and risk-taking, Journal of Financial Economics 79, 431-468.

Coles, J. L., Daniel, N. D., and Naveen, L. (2013) Calculation of compensation incentives and firm-related wealth using Execucomp: Data, program, and explanation, SSRN Scholarly Paper ID 2296381, Social Science Research Network, Rochester, NY.

Core, J. and Guay, W. (2002) Estimating the value of employee stock option portfolios and their sensitivities to price and volatility, Journal of Accounting Research 40, 613-630. DeMarzo, P. M. and Duffie, D. (1995) Corporate incentives for hedging and hedge accounting, Review of Financial Studies 8, 743-771.

DeYoung, R., Peng, E. Y., and Yan, M. (2013) Executive compensation and business policy choices at U.S. commercial banks, Journal of Financial and Quantitative Analysis 48, 165-196.

Dittmann, I. and Maug, E. (2007) Lower salaries and no options? On the optimal structure of executive pay, The Journal of Finance 62, 303-343.

Eckbo, B. E. and Thorburn, K. S. (2003) Control benefits and CEO discipline in automatic bankruptcy auctions, Journal of Financial Economics 69, 227-258.

Edmans, A. and Liu, Q. (2011) Inside debt, Review of Finance 15, 75-102.

Erkens, D. H., Hung, M., and Matos, P. (2012) Corporate governance in the 2007-2008 financial crisis: Evidence from financial institutions worldwide, Journal of Corporate Finance 18, 389-411.

Fahlenbrach, R., Prilmeier, R., and Stulz, R. M. (2012) This time is the same: Using bank performance in 1998 to explain bank performance during the recent financial crisis, The Journal of Finance 67, 2139-2185.

Fahlenbrach, R. and Stulz, R. (2011) Bank CEO incentives and the credit crisis, Journal of Financial Economics 99, 11-26.

Fitzpatrick, D., Enrich, D., and Paletta, D. (2008) PNC buys National City in bank shakeout, Wall Street Journal, October 25.

Galai, D. and Masulis, R. W. (1976) The option pricing model and the risk factor of stock, Journal of Financial Economics 3, 53-81.

Gande, A. and Kalpathy, S. L. (2015) CEO compensation and risk-taking at financial firms: Evidence from U.S. Federal loan assistance, SSRN Scholarly Paper ID 1865870 , Social Science Research Network, Rochester, NY.

Gompers, P., Ishii, J., and Metrick, A. (2003) Corporate governance and equity prices, The Quarterly Journal of Economics 118, 107-156.

Gormley, T. A., Matsa, D. A., and Milbourn, T. (2013) CEO compensation and corporate risk: Evidence from a natural experiment, Journal of Accounting and Economics 56, 79101.

Greene, W. (2010) Testing hypotheses about interaction terms in nonlinear models, Economics Letters 107, 291-296.

Guay, W. (1999) The sensitivity of CEO wealth to equity risk: An analysis of the magnitude and determinants, Journal of Financial Economics 53, 43-71.

Houston, J. and James, C. (1995) CEO compensation and bank risk. Is compensation in banking structured to promote risk taking?, Journal of Monetary Economics 36, 405-431. Ingersoll, J. E. (2006) The subjective and objective evaluation of incentive stock options, The Journal of Business 79, 453-487. 
Jensen, M. and Meckling, W. (1976) Theory of the firm: Managerial behavior, agency costs and ownership structure, Journal of Financial Economics 3, 305-360.

John, K. and Qian, Y. (2003) Incentive features in CEO compensation in the banking industry, Federal Reserve Bank of New York Economic Policy Review 9, 109-121.

John, T. A. and John, K. (1993) Top-management compensation and capital structure, The Journal of Finance 48, 949-974.

Knopf, J. D., Nam, J., and Thornton Jr, J. H. (2002) The volatility and price sensitivities of managerial stock option portfolios and corporate hedging, The Journal of Finance 57, 801-813.

Laeven, L. and Levine, R. (2009) Bank governance, regulation and risk taking, Journal of Financial Economics 93, 259-275.

Lambert, R. A., Larcker, D. F., and Verrecchia, R. E. (1991) Portfolio considerations in valuing executive compensation, Journal of Accounting Research 29, 129-149.

Lewellen, K. (2006) Financing decisions when managers are risk averse, Journal of Financial Economics 82, 551-589.

Low, A. (2009) Managerial risk-taking behavior and equity-based compensation, Journal of Financial Economics 92, 470-490.

Merton, R. C. (1973) Theory of rational option pricing, Bell Journal of Economics 4, $141-183$.

Merton, R. C. (1974) On the pricing of corporate debt: The risk structure of interest rates, The Journal of Finance 29, 449-470.

Morellec, E. (2004) Can managerial discretion explain observed leverage ratios?, Review of Financial Studies 17, 257-294.

Morellec, E., Nikolov, B., and Schürhoff, N. (2012) Corporate governance and capital structure dynamics, The Journal of Finance 67, 803-848.

Murphy, K. J. (2013) Regulating banking bonuses in the European Union: a case study in unintended consequences, European Financial Management 19, 631-657.

Muscarella, C. J. and Zhao, J. (2015) Promoting the quiet life or risk-taking? CEO severance contracts and managerial decision-making, SSRN Scholarly Paper ID 1787221, Social Science Research Network, Rochester, NY.

Nagel, S. and Purnanandam, A. (2015) Bank risk dynamics and distance to default, Working Paper, University of Michigan.

Prendergast, C. (2002) The tenuous trade-off between risk and incentives, The Journal of Political Economy 110, 1071-1102.

Rau, P. R. and Xu, J. (2013) How do ex ante severance pay contracts fit into optimal executive incentive schemes?, Journal of Accounting Research 51, 631-671.

Ross, S. A. (2004) Compensation, incentives, and the duality of risk aversion and riskiness, The Journal of Finance 59, 207-225.

Story, L. and Becker, J. (2009) Bank chief tells of U.S. pressure to buy Merrill Lynch, The New York Times, June 12.

Sundaram, R. and Yermack, D. (2007) Pay me later: Inside debt and its role in managerial compensation, The Journal of Finance 62, 1551-1588.

Uhde, A. (2016) Risk-taking incentives through excess variable compensation: Evidence from European banks, The Quarterly Review of Economics and Finance 60, 12-28.

Vallascas, F. and Hagendorff, J. (2013) CEO bonus compensation and bank default risk: Evidence from the U.S. and Europe, Financial Markets, Institutions 83 Instruments 22, $47-89$. 


\section{Appendices}

\section{Sample firms}

The following table lists the institutions included in the sample in year 2006. Firms are listed in three groups, according to the criterion used to include them in the sample. Firms in Group A are firms that are selected because their SIC code is one of the following: 602 (Commercial Banks), 603 (Savings Institutions), or 6712 (Offices of Bank Holding Companies). Firms in Group B are firms that do not meet the SIC code criterion, but are included in the sample because they are identified as a regulated institution by the National Information Center of the FFIEC (http://www.ffiec.gov/nicpubweb/nicweb/ SearchForm.aspx.), which implies that the firm controls depository institutions (such as banks or savings and loan associations). Finally, firms in Group $\mathrm{C}$ are firms that do not meet the above two criteria, but are included in the sample because of their primary dealer status as of December 2006.

\begin{tabular}{|c|c|c|}
\hline \multicolumn{3}{|c|}{ Group A) Firms selected by industry code } \\
\hline ANCHOR BANCORP WISCONSIN INC & GUARANTY FINANCIAL GROUP INC & WACHOVIA CORP \\
\hline ASTORIA FINANCIAL CORP & HANMI FINANCIAL CORP & WASHINGTON FEDERAL INC \\
\hline BANCORPSOUTH INC & HUDSON CITY BANCORP INC & WASHINGTON MUTUAL INC \\
\hline BANK MUTUAL CORP & HUNTINGTON BANCSHARES & WEBSTER FINANCIAL CORP \\
\hline BANK OF AMERICA CORP & INDEPENDENT BANK CORP/MI & WELLS FARGO \& CO \\
\hline BANK OF HAWAII CORP & INDYMAC BANCORP INC & WESTAMERICA BANCORPORATION \\
\hline BANK OF NEW YORK MELLON CORP & IRWIN FINANCIAL CORP & WHITNEY HOLDING CORP \\
\hline BANK OF THE OZARKS INC & JPMORGAN CHASE \& CO & WILMINGTON TRUST CORP \\
\hline BANKUNITED FINANCIAL CORP & KEYCORP & WILSHIRE BANCORP INC \\
\hline BB\&T CORP & M \& T BANK CORP & WINTRUST FINANCIAL CORP \\
\hline BBCN BANCORP INC & MAF BANCORP INC & ZIONS BANCORPORATION \\
\hline BBX CAPITAL CORP & MARSHALL \& ILSLEY CORP & \\
\hline BOSTON PRIVATE FINL HOLDINGS & MELLON FINANCIAL CORP & \\
\hline BROOKLINE BANCORP INC & MERCANTILE BANKSHARES CORP & Group B) Firms selected by entity type \\
\hline CASCADE BANCORP & N B T BANCORP INC & AMERICAN EXPRESS CO \\
\hline CATHAY GENERAL BANCORP & NATIONAL CITY CORP & AMERIPRISE FINANCIAL INC \\
\hline CENTER FINANCIAL CORP & NATIONAL PENN BANCSHARES INC & ASSOCIATED BANC-CORP \\
\hline CENTRAL PACIFIC FINANCIAL CP & NEW YORK CMNTY BANCORP INC & BBVA COMPASS BANCSHARES INC \\
\hline CHITTENDEN CORP & NORTHERN TRUST CORP & CAPITAL ONE FINANCIAL CORP \\
\hline CITIGROUP INC & OLD NATIONAL BANCORP & COMMERCE BANCSHARES INC \\
\hline CITY HOLDING CO & PACWEST BANCORP & COUNTRYWIDE FINANCIAL CORP \\
\hline CITY NATIONAL CORP & PEOPLE'S UNITED FINL INC & E TRADE FINANCIAL CORP \\
\hline COLONIAL BANCGROUP & PINNACLE FINL PARTNERS INC & FIFTH THIRD BANCORP \\
\hline COLUMBIA BANKING SYSTEM INC & PNC FINANCIAL SVCS GROUP INC & FRANKLIN BANK CORP \\
\hline COMERICA INC & PRIVATEBANCORP INC & FRANKLIN RESOURCES INC \\
\hline COMMERCE BANCORP INC/NJ & PROSPERITY BANCSHARES INC & INVESTORS FINANCIAL SVCS CP \\
\hline COMMUNITY BANK SYSTEM INC & PROVIDENT BANKSHARES CORP & LEHMAN BROTHERS HOLDINGS INC \\
\hline CORUS BANKSHARES INC & REGIONS FINANCIAL CORP & MORGAN STANLEY \\
\hline CULLEN/FROST BANKERS INC & $\mathrm{S} \& \mathrm{~T}$ BANCORP INC & MUFG AMERICAS HOLDINGS CORP \\
\hline DIME COMMUNITY BANCSHARES & SANTANDER HOLDINGS USA INC & POPULAR INC \\
\hline DOWNEY FINANCIAL CORP & SIMMONS FIRST NATL CP -CL A & PRICE (T. ROWE) GROUP \\
\hline EAST WEST BANCORP INC & SOUTH FINANCIAL GROUP INC & PRINCIPAL FINANCIAL GRP INC \\
\hline FIRST BANCORP P R & $\begin{array}{l}\text { STATE STREET CORP } \\
\text { ST }\end{array}$ & RAYMOND JAMES FINANCIAL CORP \\
\hline FIRST COMMONWLTH FINL CP/PA & STERLING BANCORP/NY -OLD & SCHWAB (CHARLES) CORP \\
\hline FIRST FINL BANCORP INC/OH & STERLING BANCSHARES INC/TX & SEI INVESTMENTS CO \\
\hline FIRST FINL BANKSHARES INC & STERLING FINANCIAL CORP/WA & SWS GROUP INC \\
\hline FIRST HORIZON NATIONAL CORP & SUNTRUST BANKS INC & TOMPKINS FINANCIAL CORP \\
\hline FIRST INDIANA CORP & SUSQUEHANNA BANCSHARES INC & U S BANCORP \\
\hline FIRST MIDWEST BANCORP INC & SVB FINANCIAL GROUP & \\
\hline FIRST NIAGARA FINANCIAL GRP & SYNOVUS FINANCIAL CORP & Group C) Primary dealers or \\
\hline FIRST REPUBLIC BANK & TCF FINANCIAL CORP & BEAR STEARNS COMPANIES INC \\
\hline FIRSTFED FINANCIAL CORP/CA & TD BANKNORTH INC & GOLDMAN SACHS GROUP INC \\
\hline FIRSTMERIT CORP & TRUSTCO BANK CORP/NY & MERRILL LYNCH \& CO INC \\
\hline FLAGSTAR BANCORP INC & UCBH HOLDINGS INC & \\
\hline FRONTIER FINANCIAL CORP/WA & UMB FINANCIAL CORP & \\
\hline FULTON FINANCIAL CORP & UMPQUA HOLDINGS CORP & \\
\hline GLACIER BANCORP INC & UNITED BANKSHARES INC/WV & \\
\hline GREATER BAY BANCORP & UNITED COMMUNITY BANKS INC & \\
\hline
\end{tabular}




\section{Failed firms}

The following table lists the institutions that we identify as failed in the period 2007-2010. Columns Year and Month display the last year and month, respectively, for which there is information for the corresponding firm in CRSP. The column Step displays at which step in the procedure to identify failed firms the firm was categorized as failed. The four steps of the procedure to identify failed firms, described in Section 4.1, are: 1) bank subsidiary closure (as identified by the FDIC); 2) merger discount; 3) PROQUEST keyword search; 4) Internet search.

$\begin{array}{lccc}\quad \text { Company Name } & \text { Year } & \text { Month } & \text { Step } \\ \text { BEAR STEARNS COMPANIES INC } & 2008 & 5 & 2 \\ \text { COLONIAL BANCGROUP } & 2009 & 7 & 1 \\ \text { CORUS BANKSHARES INC } & 2009 & 8 & 1 \\ \text { COUNTRYWIDE FINANCIAL CORP } & 2008 & 6 & 2 \\ \text { DOWNEY FINANCIAL CORP } & 2008 & 10 & 1 \\ \text { FIRSTFED FINANCIAL CORP } & 2009 & 2 & 1 \\ \text { FRANKLIN BANKCORP } & 2008 & 10 & 1 \\ \text { FRONTIER FINANCIAL CORP/WA } & 2010 & 4 & 1 \\ \text { INDYMAC BANCORP INC } & 2008 & 6 & 1 \\ \text { IRWIN FINANCIAL CORP } & 2009 & 8 & 1 \\ \text { LEHMAN BROTHERS HOLDINGS INC } & 2008 & 8 & 3 \\ \text { MELLON FINANCIAL CORP } & 2007 & 6 & 2 \\ \text { MERRILL LYNCH \& CO INC } & 2008 & 12 & 4 \\ \text { NATIONAL CITY CORP } & 2008 & 12 & 4 \\ \text { PROVIDENT BANKSHARES CORP } & 2009 & 4 & 4 \\ \text { SOUTH FINANCIAL GROUP INC } & 2010 & 9 & 2 \\ \text { UCBH HOLDINGS INC } & 2009 & 10 & 1 \\ \text { WACHOVIA CORP } & 2008 & 12 & 2 \\ \text { WASHINGTON MUTUAL INC } & 2008 & 8 & 1\end{array}$




\section{Tables}

Table 1: Summary Statistics of the Main Variables in Year 2006. The table reports summary statistics for the firms in the sample. S.d. denotes the standard deviation and p- $n$ denotes the nth percentile. Delta is the change in the value of the CEO's portfolio of stock and options (measured in $\$$ million) associated with a $1 \%$ change in the price of the stock of the firm. Vega is the change in the value of the CEO's option portfolio (measured in $\$$ million) associated with a change of 0.01 in the standard deviation of the price of the stock. Total pay is the total compensation received by the CEO. It comprises salary, bonus, other annual payments, restricted stock grants, long term incentive plan (LTIP) payouts, other compensation, and the value of option grants. Leverage is the quasimarket value of leverage, computed as book value of assets minus book value of equity plus market value of equity, divided by market value of equity. Market cap. is the firm's market capitalization. Market capitalization and total assets are measured in billions of dollars. Total Assets is the total assets of the firm as of December 2006 measured in billion dollars. $R O A$ (avg.) is the average return on assets over the period 2004-2006, where return on assets is measured as the ratio of operating income before depreciation over total assets at the end of the previous year. Market-to-book is the equity market-to-book ratio, defined as market capitalization over the book value of equity. Returns (avg.) is the average annual stock return in the period 2004-2006. All variables are measured in year 2006 except otherwise noted.

\begin{tabular}{lcrrrrrrr}
\hline & Count & Mean & S.d. & p-10 & p-25 & p-50 & p-75 & p-90 \\
\hline Delta & 129 & 1.34 & 4.25 & 0.03 & 0.09 & 0.35 & 1.13 & 2.93 \\
Vega & 129 & 0.27 & 0.49 & 0.00 & 0.01 & 0.06 & 0.34 & 0.80 \\
Total pay & 127 & 6.95 & 10.28 & 0.67 & 1.09 & 2.23 & 7.45 & 20.37 \\
Leverage & 129 & 6.24 & 2.88 & 3.81 & 4.77 & 5.63 & 6.97 & 9.33 \\
Market cap. & 129 & 16.04 & 39.39 & 0.62 & 1.11 & 2.15 & 12.03 & 31.49 \\
Total assets & 129 & 104.70 & 284.23 & 2.66 & 5.49 & 11.12 & 52.62 & 199.95 \\
ROA (avg.) & 129 & 0.04 & 0.05 & 0.02 & 0.03 & 0.03 & 0.04 & 0.05 \\
Market-to-book & 129 & 2.25 & 1.08 & 1.37 & 1.61 & 2.01 & 2.50 & 3.37 \\
Returns (avg.) & 129 & 0.12 & 0.11 & -0.02 & 0.05 & 0.11 & 0.17 & 0.25
\end{tabular}


Table 2: Risk-taking incentives and bank failure. The table presents estimated coefficients of different specifications of a linear probability model with Failed as the dependent variable. Failed is a dummy variable equal to 1 if the firm fails in the period from 2007 to 2010. Delta is the natural logarithm of one plus the change in the value of the CEO's portfolio of stock and options (measured in \$ million) associated with a 1\% change in the price of the stock of the firm. Vega is the natural logarithm of one plus the change in the value of the CEO's option portfolio (measured in $\$$ million) associated with a change of 0.01 in the standard deviation of the price of the stock. Leverage is the quasimarket value of leverage, computed as book value of assets minus book value of equity plus market value of equity, divided by market value of equity. Firm size is the natural logarithm of total assets. G. parachute and Severance pay are the contingent payments upon termination with and without a change in control, respectively, as in year 2006's proxy statements. Inside debt is the sum of the present value of accumulated pension benefits from all pension plans and the total aggregate balance in deferred compensation plans of the CEO at the end of 2006, as reported in ExecuComp. CEO wealth is the non-firm wealth of the CEO, as defined by Dittmann and Maug (2007). All compensation variables are logarithmic transformations of the original variables measured in millions of dollars. CEO age denotes the CEO's age in years. E-index is the Entrenchment Index, as defined by Bebchuck et al. (2009). Board size is the number of members of the board of directors. Independence is the number of independent directors divided by board size. Tenure co. measures the number of years the $\mathrm{CEO}$ has been employed at the company (irrespectively of his position). CEO Tenure measures the number of years the CEO has been in office. Number boards denotes the number of boards of listed firms at which the CEO has ever served, as reported by BoardEx. Duality is a dummy equal to one if the CEO also serves as Chairman of the board. Percent new denotes the fraction of independent directors appointed after the CEO was hired. Blockholder own. denotes the percentage of ownership in the hands of institutional blockholders (with at least $5 \%$ of the shares). Employees is the number of employees in thousands. Complexity is a dummy variable equal to one if the Federal Reserve considers the firm a complex institution. International is a dummy variable equal to one if the firm has operations outside the U.S.. Multiple banks is a dummy equal to one if the firm controls more than one commercial bank. ${ }^{*}, * *$ and *** represent significance levels at $10 \%, 5 \%$, and $1 \%$, respectively. Robust standard errors are reported in parentheses. Obs. stands for the number of observations. Failed avg. is the average of the variable Failed (i.e., the unconditional probability of failure) in the sample used in the corresponding column. $75-25$ (Lev. L) is the average difference between the predicted probability of failure if delta is at its 75th percentile and leverage is at its Lth percentile and the predicted probability of failure if delta is at its 25th percentile and leverage is at its Lth percentile. 


\begin{tabular}{|c|c|c|c|c|c|c|c|c|}
\hline & (1) & $(2)$ & (3) & (4) & (5) & (6) & (7) & (8) \\
\hline Delta & 0.130 & -0.052 & $-0.322^{* * *}$ & $-0.200^{*}$ & -0.029 & -0.122 & $-0.524^{* * *}$ & -0.122 \\
\hline & $(0.089)$ & $(0.081)$ & $(0.100)$ & $(0.103)$ & $(0.116)$ & $(0.097)$ & $(0.188)$ & $(0.110)$ \\
\hline Delta $\times$ Leverage & & $0.027^{* *}$ & $0.075^{* * * *}$ & $0.069^{* *}$ & $0.024^{*}$ & $0.029^{* *}$ & $0.124^{* * *}$ & $0.033^{* * *}$ \\
\hline Vega & -0.097 & $\begin{array}{c}(0.012) \\
0.059\end{array}$ & $\begin{array}{c}(0.028) \\
-0.025\end{array}$ & $\begin{array}{r}(0.027) \\
-0.048\end{array}$ & $\begin{array}{c}(0.013) \\
0138\end{array}$ & $\left(\begin{array}{c}0.012) \\
0.023\end{array}\right.$ & $\begin{array}{c}(0.030) \\
-0.069\end{array}$ & $(0.011)$ \\
\hline & $(0.214)$ & $(0.183)$ & $(0.222)$ & $(0.194)$ & $(0.198)$ & $(0.207)$ & $(0.182)$ & $(0.184)$ \\
\hline Leverage & & $\begin{array}{c}0.013 \\
(0.020)\end{array}$ & -0.011 & 0.000 & $\begin{array}{c}0.019 \\
(0.021)\end{array}$ & 0.003 & $-0.028^{*}$ & 0.002 \\
\hline Firm size & $\begin{array}{c}0.028 \\
(0.025)\end{array}$ & $\begin{array}{c}-0.013 \\
(0.025)\end{array}$ & $\begin{array}{c}0.005 \\
(0.042)\end{array}$ & $\begin{array}{c}-0.019 \\
(0.032)\end{array}$ & $\begin{array}{c}-0.017 \\
(0.026)\end{array}$ & $\begin{array}{c}0.003 \\
(0.038)\end{array}$ & $\begin{array}{c}-0.044 \\
(0.040)\end{array}$ & $\begin{array}{c}0.007 \\
(0.040)\end{array}$ \\
\hline Total pay & & & $\begin{array}{c}0.010 \\
(0.104)\end{array}$ & $\begin{array}{c}-0.010 \\
(0.079)\end{array}$ & & & & $\begin{array}{c}0.010 \\
(0.087)\end{array}$ \\
\hline CEO age & & & $\begin{array}{c}-0.004 \\
(0.004)\end{array}$ & & $\begin{array}{c}0.000 \\
(0.005)\end{array}$ & & & \\
\hline Severance pay & & & $\begin{array}{c}0.011 \\
(0.037)\end{array}$ & & & & & \\
\hline G. parachute & & & $\begin{array}{c}-0.013 \\
(0.028)\end{array}$ & & & & & \\
\hline Tenure co. & & & $\begin{array}{c}0.010 \\
(0.007)\end{array}$ & & & & & $\begin{array}{c}0.006 \\
(0.004)\end{array}$ \\
\hline CEO tenure & & & $\begin{array}{c}0.000 \\
(0.008)\end{array}$ & & & & & \\
\hline Number boards & & & $\begin{array}{c}-0.016 \\
(0.036)\end{array}$ & & & & & \\
\hline Inside debt & & & & $\begin{array}{c}0.008 \\
(0.036)\end{array}$ & & & & \\
\hline CEO wealth & & & & & $\begin{array}{c}-0.003 \\
(0.040)\end{array}$ & & & \\
\hline E-Index & & & & & & $\begin{array}{c}-0.010 \\
(0.027)\end{array}$ & & \\
\hline Independence & & & & & & $\begin{array}{c}0.172 \\
(0.346)\end{array}$ & & \\
\hline Board size & & & & & & $\begin{array}{c}-0.001 \\
(0.016)\end{array}$ & & $\begin{array}{c}0.002 \\
(0.012)\end{array}$ \\
\hline Blockholder own. & & & & & & $\begin{array}{c}0.600 \\
(0.424)\end{array}$ & & $0.661^{*}$ \\
\hline Percent new & & & & & & $\begin{array}{c}0.209 \\
(0.187)\end{array}$ & & \\
\hline Duality & & & & & & $\begin{array}{r}-0.006 \\
(0.097)\end{array}$ & & \\
\hline International & & & & & & & $\begin{array}{c}0.180 \\
(0.110)\end{array}$ & $\begin{array}{c}0.012 \\
(0.096)\end{array}$ \\
\hline Complexity & & & & & & & $\begin{array}{c}0.067 \\
(0.075)\end{array}$ & \\
\hline Multiple banks & & & & & & & $\begin{array}{r}-0.068 \\
(0.064)\end{array}$ & \\
\hline Employees & & & & & & & $\begin{array}{c}-0.001 \\
(0.001)\end{array}$ & \\
\hline Obs. & 129 & 129 & 98 & 118 & 110 & 93 & 94 & 110 \\
\hline Adj. $R^{2}$ & 0.041 & 0.138 & 0.092 & 0.096 & 0.166 & 0.103 & 0.160 & 0.191 \\
\hline Failed avg. & 0.147 & 0.147 & 0.143 & 0.144 & 0.136 & 0.172 & 0.117 & 0.155 \\
\hline $75-25$ (Lev. 25) & 0.087 & 0.052 & 0.025 & 0.085 & 0.056 & 0.011 & 0.045 & 0.023 \\
\hline $75-25($ Lev. 75$)$ & 0.087 & 0.092 & 0.135 & 0.185 & 0.091 & 0.053 & 0.226 & 0.070 \\
\hline
\end{tabular}


Table 3: Subsectors. The table presents estimated coefficients of different specifications of a linear probability model with Failed as the dependent variable. Failed is a dummy variable equal to 1 if the firm fails in the period from 2007 to 2010 . Columns (1) and (2) include dummies for each of the existing subsectors in the sample (commercial banks (SIC codes 602 and 6199), savings institutions (603), personal credit institutions (6141), mortgage bankers and loan correspondents (6162), security brokers and dealers (6211), and investment advice (6282)). In columns (3) and (4), investments banks are excluded from the sample. The sample in column (5) contains only Bank Holding Companies (BHCs). Delta is the natural logarithm of one plus the change in the value of the CEO's portfolio of stock and options (measured in $\$$ million) associated with a $1 \%$ change in the price of the stock of the firm. Vega is the natural logarithm of one plus the change in the value of the CEO's option portfolio (measured in $\$$ million) associated with a change of 0.01 in the standard deviation of the price of the stock. Firm size is the natural logarithm of total assets. Leverage is the quasi-market value of leverage, computed as book value of assets minus book value of equity plus market value of equity, divided by market value of equity. The specifications with controls include as controls: the natural logarithm of (one plus) total pay, the CEO tenure at the company, board size, the fraction of the shares owned by institutional blockholders, and a dummy variable equal to one if the firm has operations outside the U.S.. * ** and *** represent significance levels at $10 \%, 5 \%$, and $1 \%$, respectively. Robust standard errors are reported in parentheses. Obs. stands for the number of observations. Failed avg. is the average of the variable Failed (i.e., the unconditional probability of failure) in the sample used in the corresponding column. $75-25$ (Lev. L) is the average difference between the predicted probability of failure if delta is at its 75 th percentile and leverage is at its Lth percentile and the predicted probability of failure if delta is at its 25 th percentile and leverage is at its Lth percentile.

\begin{tabular}{|c|c|c|c|c|c|}
\hline & \multicolumn{2}{|c|}{ Subsector dummies } & \multicolumn{2}{|c|}{ No inv. banks } & \multirow{2}{*}{$\frac{\text { BHCs only }}{(5)}$} \\
\hline & (1) & (2) & (3) & (4) & \\
\hline Delta & $\begin{array}{c}-0.005 \\
(0.110)\end{array}$ & $\begin{array}{c}-0.062 \\
(0.134)\end{array}$ & $\begin{array}{c}-0.379 \\
(0.239)\end{array}$ & $\begin{array}{c}-0.579^{* *} \\
(0.235)\end{array}$ & $\begin{array}{c}-0.754^{* *} \\
(0.298)\end{array}$ \\
\hline Leverage & $\begin{array}{c}0.007 \\
(0.017)\end{array}$ & $\begin{array}{r}-0.000 \\
(0.018)\end{array}$ & $\begin{array}{c}-0.003 \\
(0.024)\end{array}$ & $\begin{array}{c}-0.025 \\
(0.019)\end{array}$ & $\begin{array}{r}-0.028^{*} \\
(0.017)\end{array}$ \\
\hline Delta $\times$ Leverage & $\begin{array}{c}0.025^{* *} \\
(0.010)\end{array}$ & $\begin{array}{l}0.031^{* * *} \\
(0.011)\end{array}$ & $\begin{array}{c}0.083^{* *} \\
(0.040)\end{array}$ & $\begin{array}{l}0.110^{* * *} \\
(0.036)\end{array}$ & $\begin{array}{l}0.154^{* * *} \\
(0.042)\end{array}$ \\
\hline Vega & $\begin{array}{c}-0.087 \\
(0.201)\end{array}$ & $\begin{array}{c}-0.147 \\
(0.244)\end{array}$ & $\begin{array}{c}0.038 \\
(0.197)\end{array}$ & $\begin{array}{c}-0.042 \\
(0.229)\end{array}$ & $\begin{array}{c}-0.063 \\
(0.291)\end{array}$ \\
\hline Firm size & $\begin{array}{c}0.003 \\
(0.025)\end{array}$ & $\begin{array}{c}-0.001 \\
(0.041)\end{array}$ & $\begin{array}{c}-0.007 \\
(0.030)\end{array}$ & $\begin{array}{c}-0.007 \\
(0.049)\end{array}$ & $\begin{array}{c}-0.078 \\
(0.048)\end{array}$ \\
\hline Controls & No & Yes & No & Yes & Yes \\
\hline Subsector dummies & Yes & Yes & No & No & No \\
\hline Obs. & 129 & 110 & 115 & 96 & 79 \\
\hline Adj. $R^{2}$ & 0.179 & 0.207 & 0.085 & 0.162 & 0.184 \\
\hline Failed avg. & 0.147 & 0.155 & 0.139 & 0.146 & 0.127 \\
\hline $75-25($ Lev. 25$)$ & 0.077 & 0.056 & 0.010 & -0.036 & -0.012 \\
\hline $75-25($ Lev. 75$)$ & 0.113 & 0.102 & 0.131 & 0.125 & 0.212 \\
\hline
\end{tabular}


Table 4: TBTF banks. The table presents estimated coefficients of different specifications of a linear probability model with Failed as the dependent variable. Failed is a dummy variable equal to 1 if the firm fails in the period from 2007 to 2010. Columns (1) and (2) include the dummy variable $T B T F-C A P$, which is equal to one for firms larger than the smallest firm (in terms of total assets as of 2006) included in the 2009 SCAP. Columns (3) and (4) include the dummy variable TBTF-rev., which is equal to one for firms larger than the largest firm (in terms of total assets as of 2006) with Failed =1. In columns 5 to 8, the sample consists of Bank Holding Companies only. Delta is the natural logarithm of one plus the change in the value of the CEO's portfolio of stock and options (measured in \$ million) associated with a $1 \%$ change in the price of the stock of the firm. Vega is the natural logarithm of one plus the change in the value of the CEO's option portfolio (measured in $\$$ million) associated with a change of 0.01 in the standard deviation of the price of the stock. Firm size is the natural logarithm of total assets. Leverage is the quasi-market value of leverage, computed as book value of assets minus book value of equity plus market value of equity, divided by market value of equity. The specifications with controls include as controls: the natural logarithm of (one plus) total pay, the CEO tenure at the company, board size, the fraction of the shares owned by institutional blockholders, and a dummy variable equal to one if the firm has operations outside the U.S.. *, ** and *** represent significance levels at $10 \%, 5 \%$, and $1 \%$, respectively. Robust standard errors are reported in parentheses. Obs. stands for the number of observations. Failed avg. is the average of the variable Failed (i.e., the unconditional probability of failure) in the sample used in the corresponding column. $75-25$ (Lev. L) is the average difference between the predicted probability of failure if delta is at its 75 th percentile and leverage is at its Lth percentile and the predicted probability of failure if delta is at its 25 th percentile and leverage is at its Lth percentile.

\begin{tabular}{|c|c|c|c|c|c|c|c|c|}
\hline & \multicolumn{4}{|c|}{ All firms } & \multicolumn{4}{|c|}{ BHCs only } \\
\hline & (1) & (2) & (3) & (4) & (5) & (6) & (7) & (8) \\
\hline Delta & $\begin{array}{c}-0.054 \\
(0.081)\end{array}$ & $\begin{array}{c}-0.128 \\
(0.114)\end{array}$ & $\begin{array}{c}-0.056 \\
(0.086)\end{array}$ & $\begin{array}{c}-0.101 \\
(0.112)\end{array}$ & $\begin{array}{c}-0.432^{* *} \\
(0.188)\end{array}$ & $\begin{array}{c}-0.578^{* * * *} \\
(0.182)\end{array}$ & $\begin{array}{c}-0.543^{* * * *} \\
(0.189)\end{array}$ & $\begin{array}{c}-0.612^{\text {**** }} \\
(0.184)\end{array}$ \\
\hline Leverage & $\begin{array}{c}0.013 \\
(0.020)\end{array}$ & $\begin{array}{c}0.001 \\
(0.018)\end{array}$ & $\begin{array}{c}0.012 \\
(0.020)\end{array}$ & $\begin{array}{c}0.001 \\
(0.018)\end{array}$ & $\begin{array}{c}-0.021 \\
(0.015)\end{array}$ & $\begin{array}{c}-0.023 \\
(0.016)\end{array}$ & $\begin{array}{r}-0.027^{*} \\
(0.014)\end{array}$ & $\begin{array}{r}-0.025^{*} \\
(0.015)\end{array}$ \\
\hline Delta $\times$ Leverage & $\begin{array}{l}0.028^{* *} \\
(0.012)\end{array}$ & $\begin{array}{l}0.033^{* * * *} \\
(0.011)\end{array}$ & $\begin{array}{l}0.028^{* *} \\
(0.014)\end{array}$ & $\begin{array}{l}0.032^{* *} \\
(0.012)\end{array}$ & $\begin{array}{l}0.106^{* * *} \\
(0.033)\end{array}$ & $\begin{array}{l}0.133^{* * * *} \\
(0.031)\end{array}$ & $\begin{array}{l}0.128^{* * *} \\
(0.031)\end{array}$ & $\begin{array}{l}0.146^{\text {**** }} \\
(0.027)\end{array}$ \\
\hline Vega & $\begin{array}{c}0.072 \\
(0.184)\end{array}$ & $\begin{array}{c}0.050 \\
(0.175)\end{array}$ & $\begin{array}{c}0.011 \\
(0.179)\end{array}$ & $\begin{array}{c}-0.034 \\
(0.181)\end{array}$ & $\begin{array}{c}-0.045 \\
(0.186)\end{array}$ & $\begin{array}{c}-0.045 \\
(0.181)\end{array}$ & $\begin{array}{c}-0.204 \\
(0.191)\end{array}$ & $\begin{array}{c}-0.304 \\
(0.216)\end{array}$ \\
\hline TBTF-CAP & $\begin{array}{c}-0.021 \\
(0.111)\end{array}$ & $\begin{array}{c}-0.055 \\
(0.146)\end{array}$ & & & $\begin{array}{c}-0.025 \\
(0.144)\end{array}$ & $\begin{array}{c}-0.132 \\
(0.178)\end{array}$ & & \\
\hline Firm size & $\begin{array}{c}-0.011 \\
(0.030)\end{array}$ & $\begin{array}{c}0.012 \\
(0.036)\end{array}$ & $\begin{array}{c}0.013 \\
(0.028)\end{array}$ & $\begin{array}{c}0.038 \\
(0.042)\end{array}$ & $\begin{array}{c}-0.012 \\
(0.038)\end{array}$ & $\begin{array}{r}-0.068^{*} \\
(0.035)\end{array}$ & $\begin{array}{c}0.034 \\
(0.036)\end{array}$ & $\begin{array}{c}-0.024 \\
(0.045)\end{array}$ \\
\hline TBTF-rev. & & & $\begin{array}{c}-0.431^{* * * *} \\
(0.126)\end{array}$ & $\begin{array}{c}-0.417^{* * * *} \\
(0.139)\end{array}$ & & & $\begin{array}{c}-0.574^{* * * *} \\
(0.190)\end{array}$ & $\begin{array}{c}-0.571^{* *} \\
(0.222)\end{array}$ \\
\hline Controls & No & Yes & No & Yes & No & Yes & No & Yes \\
\hline Obs. & 129 & 110 & 129 & 110 & 94 & 81 & 94 & 81 \\
\hline Adj. $R^{2}$ & 0.131 & 0.184 & 0.167 & 0.221 & 0.112 & 0.172 & 0.177 & 0.234 \\
\hline Failed avg. & 0.147 & 0.155 & 0.147 & 0.155 & 0.117 & 0.123 & 0.117 & 0.123 \\
\hline $75-25$ (Lev. 25) & 0.052 & 0.021 & 0.051 & 0.035 & 0.050 & 0.037 & 0.044 & 0.056 \\
\hline $75-25($ Lev. 75$)$ & 0.092 & 0.070 & 0.092 & 0.082 & 0.206 & 0.231 & 0.230 & 0.269 \\
\hline
\end{tabular}


Table 5: Alternative specifications. The table presents estimated coefficients of different specifications with Failed as the dependent variable. Columns 1 and 2 report coefficients of a linear probability model. Columns 3 and 4 report coefficients of a probit model. Columns 5 and 6 report coefficients of a logit model. Failed is a dummy variable equal to 1 if the firm fails in the period from 2007 to 2010. Delta is the change in the value of the CEO's portfolio of stock and options (measured in \$ million) associated with a $1 \%$ change in the price of the stock of the firm. Vega is the change in the value of the CEO's option portfolio (measured in $\$$ million) associated with a change of 0.01 in the standard deviation of the price of the stock. In all specifications, Delta, Vega, and total pay enter linearly (instead of as logarithmic transformations). Leverage is the quasi-market value of leverage, computed as book value of assets minus book value of equity plus market value of equity, divided by market value of equity. Firm size is the natural logarithm of total assets. The specifications with controls include as controls: total pay, the CEO tenure at the company, board size, the fraction of the shares owned by institutional blockholders, and a dummy variable equal to one if the firm has operations outside the U.S.. *, ** and *** represent significance levels at $10 \%, 5 \%$, and $1 \%$, respectively. Robust standard errors are reported in parentheses. Obs. stands for the number of observations. Failed avg. is the average of the variable Failed (i.e., the unconditional probability of failure) in the sample used in the corresponding column. $75-25$ (Lev. L) is the average difference between the predicted probability of failure if delta is at its 75 th percentile and leverage is at its Lth percentile and the predicted probability of failure if delta is at its 25 th percentile and leverage is at its Lth percentile.

\begin{tabular}{|c|c|c|c|c|c|c|}
\hline & \multicolumn{2}{|c|}{ Linear Model } & \multicolumn{2}{|c|}{ Probit } & \multicolumn{2}{|c|}{ Logit } \\
\hline & $(1)$ & $(2)$ & (3) & (4) & (5) & (6) \\
\hline Delta(lin.) & $\begin{array}{c}-0.009 \\
(0.017)\end{array}$ & $\begin{array}{c}-0.027 \\
(0.022)\end{array}$ & $\begin{array}{c}-0.424 \\
(0.336)\end{array}$ & $\begin{array}{c}-0.566 \\
(0.396)\end{array}$ & $\begin{array}{c}-0.766 \\
(0.644)\end{array}$ & $\begin{array}{r}-0.980 \\
(0.808)\end{array}$ \\
\hline Leverage & $\begin{array}{c}0.024 \\
(0.019)\end{array}$ & $\begin{array}{c}0.015 \\
(0.019)\end{array}$ & $\begin{array}{c}0.038 \\
(0.068)\end{array}$ & $\begin{array}{c}-0.018 \\
(0.064)\end{array}$ & $\begin{array}{c}0.059 \\
(0.115)\end{array}$ & $\begin{array}{r}-0.023 \\
(0.108)\end{array}$ \\
\hline Delta(lin.) $\times$ Leverage & $\begin{array}{c}0.005^{* *} \\
(0.003)\end{array}$ & $\begin{array}{c}0.005^{* *} \\
(0.003)\end{array}$ & $\begin{array}{c}0.091^{*} \\
(0.047)\end{array}$ & $\begin{array}{r}0.118^{*} \\
(0.066)\end{array}$ & $\begin{array}{c}0.164^{*} \\
(0.094)\end{array}$ & $\begin{array}{r}0.219^{*} \\
(0.133)\end{array}$ \\
\hline Vega (lin.) & $\begin{array}{c}0.084 \\
(0.113)\end{array}$ & $\begin{array}{c}0.033 \\
(0.111)\end{array}$ & $\begin{array}{c}0.258 \\
(0.526)\end{array}$ & $\begin{array}{c}0.116 \\
(0.566)\end{array}$ & $\begin{array}{c}0.536 \\
(0.923)\end{array}$ & $\begin{array}{c}0.206 \\
(1.057)\end{array}$ \\
\hline Firm size & $\begin{array}{c}-0.008 \\
(0.025)\end{array}$ & $\begin{array}{c}-0.003 \\
(0.038)\end{array}$ & $\begin{array}{c}-0.074 \\
(0.109)\end{array}$ & $\begin{array}{c}0.036 \\
(0.178)\end{array}$ & $\begin{array}{r}-0.152 \\
(0.195)\end{array}$ & $\begin{array}{c}0.119 \\
(0.363)\end{array}$ \\
\hline Controls & No & Yes & No & Yes & No & Yes \\
\hline $\begin{array}{l}\text { Obs. } \\
\text { Adj. } R^{2}\end{array}$ & $\begin{array}{r}129 \\
0.121\end{array}$ & $\begin{array}{r}110 \\
0.177\end{array}$ & 129 & 110 & 129 & 110 \\
\hline Pseudo- $R^{2}$ & & & 0.185 & 0.285 & 0.183 & 0.286 \\
\hline Failed avg. & 0.147 & 0.155 & 0.145 & 0.152 & 0.147 & 0.155 \\
\hline $75-25$ (Lev. 25) & 0.016 & -0.001 & 0.001 & -0.000 & 0.001 & 0.006 \\
\hline $75-25$ (Lev. 75) & 0.028 & 0.011 & 0.044 & 0.048 & 0.042 & 0.054 \\
\hline
\end{tabular}


Table 6: Pre-crisis performance. The table presents estimated coefficients of different specifications of a linear probability model with Failed as the dependent variable. Failed is a dummy variable equal to 1 if the firm fails in the period from 2007 to 2010 . Delta is the natural logarithm of one plus the change in the value of the CEO's portfolio of stock and options (measured in $\$$ million) associated with a $1 \%$ change in the price of the stock of the firm. Vega is the natural logarithm of one plus the change in the value of the CEO's option portfolio (measured in \$ million) associated with a change of 0.01 in the standard deviation of the price of the stock. Leverage is the quasi-market value of leverage, computed as book value of assets minus book value of equity plus market value of equity, divided by market value of equity. Firm size is the natural logarithm of total assets. ROA (avg.) is the average return on assets over the period from 2004 to 2006 , where return on assets is measured as the ratio of operating income before depreciation over total assets at the end of the previous year. Market-to-book is the equity market-to-book ratio, defined as market capitalization over the book value of equity. Returns (avg.) is the average annual stock return in the period from 2004 to 2006. The specifications with controls include as controls: the natural logarithm of (one plus) total pay, the CEO tenure at the company, board size, the fraction of the shares owned by institutional blockholders, and a dummy variable equal to one if the firm has operations outside the U.S.. *, ** and *** represent significance levels at $10 \%, 5 \%$, and $1 \%$, respectively. Robust standard errors are reported in parentheses. Obs. stands for the number of observations. Dep. var. avg. is the average of the dependent variable in the sample used in the corresponding column. $75-25$ (Lev. $L$ ) is the average difference between the predicted probability of failure if delta is at its 75 th percentile and leverage is at its Lth percentile and the predicted probability of failure if delta is at its 25 th percentile and leverage is at its Lth percentile.

\begin{tabular}{|c|c|c|c|c|c|c|}
\hline & $(1)$ & $(2)$ & $(3)$ & (4) & $(5)$ & (6) \\
\hline Delta & $\begin{array}{c}-0.034 \\
(0.127)\end{array}$ & $\begin{array}{c}-0.100 \\
(0.153)\end{array}$ & $\begin{array}{c}-0.048 \\
(0.126)\end{array}$ & $\begin{array}{c}-0.128 \\
(0.152)\end{array}$ & $\begin{array}{c}-0.025 \\
(0.147)\end{array}$ & $\begin{array}{c}-0.072 \\
(0.162)\end{array}$ \\
\hline Leverage & $\begin{array}{c}0.024 \\
(0.022)\end{array}$ & $\begin{array}{c}0.010 \\
(0.020)\end{array}$ & $\begin{array}{c}0.016 \\
(0.022)\end{array}$ & $\begin{array}{c}0.001 \\
(0.021)\end{array}$ & $\begin{array}{c}0.009 \\
(0.020)\end{array}$ & $\begin{array}{c}-0.005 \\
(0.019)\end{array}$ \\
\hline Delta $\times$ Leverage & $\begin{array}{r}0.022^{*} \\
(0.013)\end{array}$ & $\begin{array}{c}0.029^{* *} \\
(0.012)\end{array}$ & $\begin{array}{r}0.025^{*} \\
(0.014)\end{array}$ & $\begin{array}{c}0.033^{* *} \\
(0.013)\end{array}$ & $\begin{array}{r}0.026^{*} \\
(0.014)\end{array}$ & $\begin{array}{c}0.030^{* * *} \\
(0.012)\end{array}$ \\
\hline Vega & $\begin{array}{c}0.018 \\
(0.212)\end{array}$ & $\begin{array}{c}-0.002 \\
(0.223)\end{array}$ & $\begin{array}{c}0.064 \\
(0.204)\end{array}$ & $\begin{array}{c}0.002 \\
(0.222)\end{array}$ & $\begin{array}{c}0.020 \\
(0.205)\end{array}$ & $\begin{array}{c}-0.049 \\
(0.222)\end{array}$ \\
\hline Firm size & $\begin{array}{r}-0.019 \\
(0.027)\end{array}$ & $\begin{array}{c}0.008 \\
(0.046)\end{array}$ & $\begin{array}{c}-0.012 \\
(0.028)\end{array}$ & $\begin{array}{c}0.006 \\
(0.050)\end{array}$ & $\begin{array}{r}-0.010 \\
(0.027)\end{array}$ & $\begin{array}{c}-0.005 \\
(0.048)\end{array}$ \\
\hline ROA (avg.) & $\begin{array}{r}6.057^{*} \\
(3.548)\end{array}$ & $\begin{array}{l}3.900 \\
(3.684)\end{array}$ & & & & \\
\hline Returns (avg.) & & & $\begin{array}{c}0.151 \\
(0.324)\end{array}$ & $\begin{array}{c}-0.109 \\
(0.359)\end{array}$ & & \\
\hline Market-to-book & & & & & $\begin{array}{c}-0.034 \\
(0.040)\end{array}$ & $\begin{array}{r}-0.060 \\
(0.041)\end{array}$ \\
\hline Controls & No & Yes & No & Yes & No & Yes \\
\hline Obs. & 125 & 106 & 125 & 106 & 125 & 106 \\
\hline Adj. $R^{2}$ & 0.157 & 0.188 & 0.129 & 0.177 & 0.132 & 0.189 \\
\hline Failed avg. & 0.152 & 0.160 & 0.152 & 0.160 & 0.152 & 0.160 \\
\hline $75-25$ (Lev. 25) & 0.047 & 0.026 & 0.049 & 0.020 & 0.067 & 0.047 \\
\hline $75-25$ (Lev. 75) & 0.080 & 0.069 & 0.086 & 0.068 & 0.106 & 0.091 \\
\hline
\end{tabular}


Table 7: Alternative risk measures: DD and EDF. The table presents estimated coefficients of OLS regressions (columns 1 and 2) and Tobit regressions (columns 3 and 4). In columns 1 and 2, the dependent variable is the average, adjusted for attrition as described in the text, over the period from 2007 to 2010 of $D D$ (distance to default), as defined by Bharath and Shumway (2008). In columns 3 and 4, the dependent variable is the average, adjusted for attrition as described in the text, over the period from 2007 to 2010 of $E D F$ (expected default frequency), defined as $\Phi(-D D)$, where $\Phi$ is the standard normal distribution function. Delta is the natural logarithm of one plus the change in the value of the CEO's portfolio of stock and options (measured in $\$$ million) associated with a $1 \%$ change in the price of the stock of the firm. Vega is the natural logarithm of one plus the change in the value of the CEO's option portfolio (measured in $\$$ million) associated with a change of 0.01 in the standard deviation of the price of the stock. Firm size is the natural logarithm of total assets, Leverage is the quasi-market value of leverage, computed as book value of assets minus book value of equity plus market value of equity, divided by market value of equity. The specifications with controls include as controls: the natural logarithm of (one plus) total pay, the CEO tenure at the company, board size, the fraction of the shares owned by institutional blockholders, and a dummy variable equal to one if the firm has operations outside the U.S.. *, ** and *** represent significance levels at $10 \%$, $5 \%$, and $1 \%$, respectively. Robust standard errors are reported in parentheses. Obs. stands for the number of observations. Dep. var. avg. is the average of the dependent variable in the sample used in the corresponding column. $75-25$ (Lev. L) is the average difference between the predicted value of the dependent variable if delta is at its 75th percentile and leverage is at its Lth percentile and the predicted value of the dependent variable if delta is at its 25th percentile and leverage is at its Lth percentile.

\begin{tabular}{|c|c|c|c|c|}
\hline & \multicolumn{2}{|c|}{ DD } & \multicolumn{2}{|c|}{ EDF } \\
\hline & (1) & $(2)$ & (3) & (4) \\
\hline \multirow[t]{2}{*}{ Delta } & $3.963^{* * *}$ & $3.674^{* * *}$ & $-0.392^{* * *}$ & $-0.430^{* * *}$ \\
\hline & $(1.032)$ & $(0.996)$ & $(0.077)$ & $(0.108)$ \\
\hline \multirow[t]{2}{*}{ Leverage } & -0.099 & -0.047 & 0.013 & 0.004 \\
\hline & $(0.107)$ & $(0.081)$ & $(0.012)$ & $(0.011)$ \\
\hline \multirow[t]{2}{*}{ Delta $\times$ Leverage } & $-0.313^{* * *}$ & $-0.316^{* * *}$ & $0.042^{* *}$ & $0.055^{* * *}$ \\
\hline & $(0.107)$ & $(0.088)$ & $(0.016)$ & $(0.019)$ \\
\hline \multirow[t]{2}{*}{ Vega } & $-3.193^{* * *}$ & $-3.358^{* * *}$ & 0.094 & -0.006 \\
\hline & $(1.217)$ & $(1.246)$ & $(0.133)$ & $(0.131)$ \\
\hline \multirow[t]{2}{*}{ Firm size } & 0.021 & $-0.703^{* *}$ & 0.015 & 0.033 \\
\hline & $(0.168)$ & $(0.284)$ & $(0.020)$ & $(0.034)$ \\
\hline Controls & No & Yes & No & Yes \\
\hline Obs. & 117 & 102 & 119 & 103 \\
\hline Adj. $R^{2}$ & 0.363 & 0.422 & & \\
\hline Pseudo-R ${ }^{2}$ & & & 0.418 & 0.514 \\
\hline Dep. var. avg. & 0.145 & 0.161 & 0.834 & 0.851 \\
\hline $75-25($ Lev. 25) & 1.644 & 1.443 & -0.128 & -0.112 \\
\hline $75-25($ Lev. 75$)$ & 1.188 & 0.982 & -0.067 & -0.032 \\
\hline
\end{tabular}


Table 8: Alternative risk measures: measures based on market returns. The table presents estimated coefficients of OLS regressions, except for column 4, which reports estimated coefficients of a Tobit model. In column 1, the dependent variable is stock return volatility, measured as the standard deviation of daily returns over the period from $07 / 01 / 2007$ to $12 / 31 / 2008$, for firms with at least 60 days of trading. In column 2 , the dependent variable is the market beta measured over the period from 07/01/2007 to $12 / 31 / 2008$. To measure beta we use the CRSP value-weighted index return, including dividends, as the market return. In columns 3 to 5 , the dependent variable (BHR) is the buy-and-hold returns from $07 / 01 / 2007$ to $12 / 31 / 2008$. In column 4 , buy-and-hold returns of failed firms are converted to -1 and the coefficients are the estimated coefficients of a Tobit model. In column 5, only Bank Holding Companies are included in the sample. Delta is the natural logarithm of one plus the change in the value of the CEO's portfolio of stock and options (measured in $\$$ million) associated with a $1 \%$ change in the price of the stock of the firm. Vega is the natural logarithm of one plus the change in the value of the CEO's option portfolio (measured in \$ million) associated with a change of 0.01 in the standard deviation of the price of the stock. Leverage is the quasi-market value of leverage, computed as book value of assets minus book value of equity plus market value of equity, divided by market value of equity. Firm size is the natural logarithm of total assets. The controls are: the natural logarithm of (one plus) total pay, the CEO tenure at the company, board size, the fraction of the shares owned by institutional blockholders, and a dummy variable equal to one if the firm has operations outside the U.S.. *, ** and *** represent significance levels at $10 \%, 5 \%$, and $1 \%$, respectively. Robust standard errors are reported in parentheses. Obs. stands for the number of observations. Dep. var. avg. is the average of the dependent variable in the sample used in the corresponding column. $75-25$ (Lev. L) is the average difference between the predicted value of the dependent variable if delta is at its 75 th percentile and leverage is at its Lth percentile and the predicted value of the dependent variable if delta is at its 25 th percentile and leverage is at its Lth percentile.

\begin{tabular}{|c|c|c|c|c|c|}
\hline & \multirow{2}{*}{$\frac{\text { Volatility }}{(1)}$} & \multirow{2}{*}{$\frac{\text { Beta }}{(2)}$} & \multicolumn{3}{|c|}{ BHR } \\
\hline & & & (3) & (4) & $(5)$ \\
\hline \multirow[t]{2}{*}{ Delta } & -0.047 & -0.106 & -0.021 & 0.238 & $0.573^{* * *}$ \\
\hline & $(0.074)$ & $(0.108)$ & $(0.123)$ & $(0.170)$ & $(0.144)$ \\
\hline \multirow[t]{2}{*}{ Leverage } & 0.023 & 0.024 & -0.001 & 0.018 & $0.046^{* * *}$ \\
\hline & $(0.018)$ & $(0.019)$ & $(0.029)$ & $(0.027)$ & $(0.016)$ \\
\hline \multirow{2}{*}{ Delta $\times$ Leverage } & 0.013 & $0.020^{*}$ & -0.010 & $-0.074^{* *}$ & $-0.109^{* * *}$ \\
\hline & $(0.010)$ & $(0.012)$ & $(0.015)$ & $(0.035)$ & $(0.029)$ \\
\hline \multirow{2}{*}{ Vega } & -0.025 & 0.023 & $0.318^{*}$ & $0.485^{* *}$ & $0.428^{* * *}$ \\
\hline & $(0.144)$ & $(0.228)$ & $(0.164)$ & $(0.194)$ & $(0.150)$ \\
\hline \multirow[t]{2}{*}{ Firm size } & $0.058^{*}$ & 0.015 & $-0.141^{* * *}$ & $-0.098^{* *}$ & $-0.111^{* *}$ \\
\hline & $(0.033)$ & $(0.040)$ & $(0.043)$ & $(0.046)$ & $(0.042)$ \\
\hline Controls & Yes & Yes & Yes & Yes & Yes \\
\hline Obs. & 103 & 103 & 107 & 108 & 79 \\
\hline Adj. $R^{2}$ & 0.367 & 0.563 & 0.297 & & 0.296 \\
\hline Pseudo- $\mathrm{R}^{2}$ & & & & 0.333 & \\
\hline Dep. var. avg. & 0.820 & 1.473 & -0.402 & -0.482 & -0.346 \\
\hline $75-25$ (Lev. 25) & 0.010 & -0.007 & -0.047 & -0.077 & 0.035 \\
\hline $75-25$ (Lev. 75) & 0.030 & 0.023 & -0.062 & -0.185 & -0.125 \\
\hline
\end{tabular}


Table 9: Incentives and risk before and after the crisis. The table presents estimated coefficients of OLS regressions. In columns 1 and 2, the dependent variable is the average over the period from 2003 to 2006 of $D D$ (distance to default), as defined by Bharath and Shumway (2008). In columns 3 and 4, the dependent variable is the average over the period from 2003 to 2006 of $E D F$ (expected default frequency), defined as $\Phi(-D D)$, where $\Phi$ is the standard normal distribution function. In columns 5 and 6, the dependent variable is the average over the period from 2011 to 2014 of $D D$. In columns 7 and 8, the dependent variable is the average over the period from 2011 to 2014 of EDF. Delta is the natural logarithm of one plus the change in the value of the CEO's portfolio of stock and options (measured in $\$$ million) associated with a $1 \%$ change in the price of the stock of the firm. Vega is the natural logarithm of one plus the change in the value of the CEO's option portfolio (measured in $\$$ million) associated with a change of 0.01 in the standard deviation of the price of the stock. Firm size is the natural logarithm of total assets, Leverage is the quasi-market value of leverage, computed as book value of assets minus book value of equity plus market value of equity, divided by market value of equity. The specifications with controls include as controls: the natural logarithm of (one plus) total pay, the CEO tenure at the company, board size, the fraction of the shares owned by institutional blockholders, and a dummy variable equal to one if the firm has operations outside the U.S.. All independent variables in columns (1) to (4) are measured in 2002. All independent variables in columns (5) to (8) are measured in 2010. *, ** and *** represent significance levels at $10 \%, 5 \%$, and $1 \%$, respectively. Robust standard errors are reported in parentheses. Obs. stands for the number of observations. Dep. var. avg. is the average of the dependent variable in the sample used in the corresponding column. $75-25$ (Lev. L) is the average difference between the predicted value of the dependent variable if delta is at its 75 th percentile and leverage is at its Lth percentile and the predicted value of the dependent variable if delta is at its 25 th percentile and leverage is at its Lth percentile.

\begin{tabular}{|c|c|c|c|c|c|c|c|c|}
\hline & \multicolumn{4}{|c|}{ 2003-2006 } & \multicolumn{4}{|c|}{ 2011-2014 } \\
\hline & \multicolumn{2}{|c|}{$\mathrm{DD}$} & \multicolumn{2}{|c|}{ EDF } & \multicolumn{2}{|c|}{$\mathrm{DD}$} & \multicolumn{2}{|c|}{ EDF } \\
\hline & (1) & $(2)$ & (3) & (4) & (5) & (6) & (7) & (8) \\
\hline Delta & $\begin{array}{l}4.045^{* * *} \\
(1.284)\end{array}$ & $\begin{array}{l}3.661^{* * *} \\
(1.284)\end{array}$ & $\begin{array}{c}0.005 \\
(0.013)\end{array}$ & $\begin{array}{c}-0.023 \\
(0.014)\end{array}$ & $\begin{array}{c}2.599 \\
(1.974)\end{array}$ & $\begin{array}{l}6.585^{* *} \\
(2.520)\end{array}$ & $\begin{array}{c}-0.024 \\
(0.056)\end{array}$ & $\begin{array}{c}-0.120^{* * *} \\
(0.042)\end{array}$ \\
\hline Leverage & $\begin{array}{c}0.111 \\
(0.097)\end{array}$ & $\begin{array}{c}0.022 \\
(0.176)\end{array}$ & $\begin{array}{c}0.003 \\
(0.003)\end{array}$ & $\begin{array}{c}-0.001 \\
(0.003)\end{array}$ & $\begin{array}{c}-0.002 \\
(0.012)\end{array}$ & $\begin{array}{c}-0.025^{* *} \\
(0.010)\end{array}$ & $\begin{array}{c}0.002 \\
(0.001)\end{array}$ & $\begin{array}{l}0.002^{* * *} \\
(0.000)\end{array}$ \\
\hline Delta $\times$ Leverage & $\begin{array}{c}-0.268^{* *} \\
(0.121)\end{array}$ & $\begin{array}{c}-0.114 \\
(0.135)\end{array}$ & $\begin{array}{c}-0.002 \\
(0.002)\end{array}$ & $\begin{array}{c}0.001 \\
(0.002)\end{array}$ & $\begin{array}{c}-0.102 \\
(0.083)\end{array}$ & $\begin{array}{c}-0.623^{* *} \\
(0.256)\end{array}$ & $\begin{array}{c}0.001 \\
(0.004)\end{array}$ & $\begin{array}{c}0.011^{*} \\
(0.005)\end{array}$ \\
\hline Vega & $\begin{array}{c}-3.075 \\
(2.041)\end{array}$ & $\begin{array}{c}-0.102 \\
(2.423)\end{array}$ & $\begin{array}{c}-0.019 \\
(0.037)\end{array}$ & $\begin{array}{c}-0.014 \\
(0.038)\end{array}$ & $\begin{array}{c}0.602 \\
(2.017)\end{array}$ & $\begin{array}{c}-0.673 \\
(1.807)\end{array}$ & $\begin{array}{c}-0.143^{* *} \\
(0.063)\end{array}$ & $\begin{array}{r}-0.097^{*} \\
(0.056)\end{array}$ \\
\hline Firm size & $\begin{array}{c}0.177 \\
(0.544)\end{array}$ & $\begin{array}{c}-0.586 \\
(0.731)\end{array}$ & $\begin{array}{c}-0.005 \\
(0.008)\end{array}$ & $\begin{array}{c}-0.010 \\
(0.010)\end{array}$ & $\begin{array}{l}-0.105 \\
(0.136)\end{array}$ & $\begin{array}{c}-0.106 \\
(0.158)\end{array}$ & $\begin{array}{l}0.024^{* * *} \\
(0.006)\end{array}$ & $\begin{array}{l}0.033^{* * *} \\
(0.010)\end{array}$ \\
\hline Controls & No & Yes & No & Yes & No & Yes & No & Yes \\
\hline Obs. & 107 & 74 & 107 & 74 & 121 & 93 & 121 & 93 \\
\hline Adj. $R^{2}$ & 0.318 & 0.471 & 0.002 & -0.044 & 0.078 & 0.321 & 0.154 & 0.161 \\
\hline Dep. var. avg. & 3.868 & 3.975 & 0.036 & 0.032 & 2.970 & 3.036 & 0.162 & 0.153 \\
\hline $75-25($ Lev. 25$)$ & 1.598 & 1.832 & -0.002 & -0.010 & 0.569 & 0.711 & -0.005 & -0.014 \\
\hline $75-25$ (Lev. 75) & 1.034 & 1.591 & -0.005 & -0.008 & 0.414 & -0.241 & -0.004 & 0.003 \\
\hline
\end{tabular}




\section{Figures}

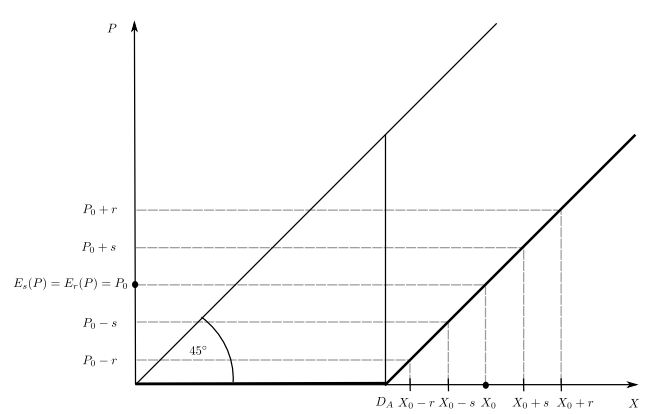

(a) Firm A: Low Leverage

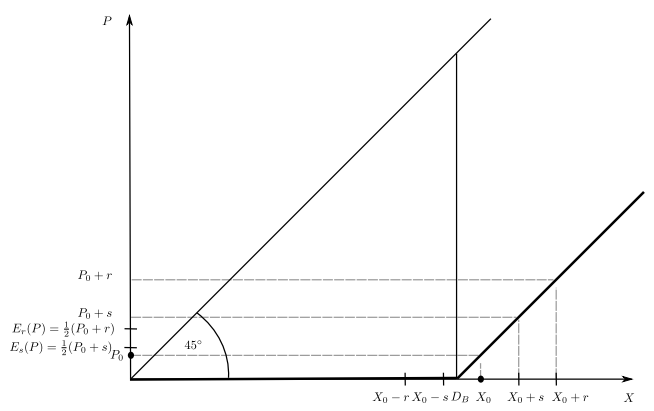

(b) Firm B: High Leverage

Fig. 1: Leverage and Risk-Taking Incentives. The figures depict the relation between the value of the firm $(X)$ and the payoff $(P)$ to an equity holder for two different firms $(A$ and $B)$, which differ only in the face value of their debt $(D)$. Firm $B$ in Panel (b) has a higher face value of debt than firm $A$ in Panel (a) $\left(D_{B}>D_{A}\right)$ and a higher leverage $\left(\frac{D_{B}}{X_{0}}>\frac{D_{A}}{X_{0}}\right)$. We assume that firms are liquidated at debt maturity after the debt is repaid, so $P$ can be understood as shareholders' liquidating dividend. In both figures, the thick line represents the payoff to equity holders at debt maturity $(P)$ as a function of the value of the firm $(X)$. The current firm value for either firm is $X_{0}$ and either firm may undertake one of two projects, safe $(s)$ or risky $(r)$. The value of the firm at debt maturity is assumed to be either $X_{0}-k$, with probability $1 / 2$, or $X_{0}+k$, with probability $1 / 2$, where $k=s$ for project $s, k=r$ for project $r$, and $r>s$. Thus, the distribution of firm value under project $r$ is a mean-preserving spread of the distribution under project $r . P_{0}=X_{0}-D$ denotes the value of the firm's equity if firm value were $X_{0}$ at debt maturity. For firm A in Panel (a) the expected equity value upon liquidation is the same for both projects: $E_{s}(P)=\frac{1}{2}\left(P_{0}-s\right)+\frac{1}{2}\left(P_{0}+s\right)=P_{0}=\frac{1}{2}\left(P_{0}-r\right)+\frac{1}{2}\left(P_{0}+r\right)=$ $E_{r}(P)$. For firm $B$ in Panel (b), equity value is zero if the project returns are negative. Therefore: $E_{s}(P)=\frac{1}{2}\left(P_{0}+s\right)<\frac{1}{2}\left(P_{0}+r\right)=E_{r}(P)$. 